\title{
Etik İklimin Kurumsal İtibar ve Kurumsal Sürdürülebilirlik Yaklaşımına Etkisi* (Impact of Ethical Climate on Corporate Reputation and Corporate Sustainability Approach)
}

\section{Gülcan AYRAL iD a Nüket SARACEL iD b}

a Doğuş Üniversitesi, İşletme Bölümü Doktora Programı, İstanbul, Türkiye. gulcanayral@gmail.com

b Doğuş Üniversitesi, İşletme Bölümü, İstanbul, Türkiye. nsaracel@dogus.edu.tr

\begin{tabular}{|c|c|}
\hline MAKALE BİLGİsí & ÖZET \\
\hline Anahtar Kelimeler: & Amaç - Günümüz yönetim anlayışında oldukça önemli bir yere sahip olan etik iklim, kurumsal itibar \\
\hline Etik & ve kurumsal sürdürülebilirlik uygulamaları, kurumları rakiplerinden farklı kılan özgün temel \\
\hline Etik iklim & nunun etkileşimini bilimsel olarak ortaya koymak \\
\hline Kurumsal itibar & sağlamada bu etkileşimin önemi konusunda farkındalık yaratmaktır. \\
\hline $\begin{array}{l}\text { Kurumsal sürdürülebilirlik } \\
\text { Yapısal eşitlik modeli. }\end{array}$ & $\begin{array}{l}\text { Yöntem - Çalışmada, birden çok değişken arasındaki karmaşık ilişkileri modelleyen yapısal eşitlik } \\
\text { modeli (YEM) kullanılmıştır. Araştırma, basit tesadüfi örneklemeyle, Türkiye'nin başarılı ve itibarlı } \\
\text { kurumlarında çalışan } 448 \text { yönetici üzerinde, nicel veri toplama yöntemlerinden anket ile yapılmıştır. }\end{array}$ \\
\hline Gönderilme Tarihi 26 Mayıs & Veriler Yapısal Eşitlik Modeli SmartPLS uygulaması ile analiz edilmiştir. \\
\hline $\begin{array}{l}2021 \\
\text { Revizyon Tarihi } 11 \text { Ağustos }\end{array}$ & $\begin{array}{l}\text { Bulgular - Analiz sonuçlarına göre, etik iklimin kurumsal itibar ve sürdürülebilirliğe anlamlı ve pozitif } \\
\text { bir etkisi olduğu, kurum itibarının da bu etkide aracı rolünün bulunduğu tespit edilmiştir. }\end{array}$ \\
\hline Kabul Tarihi 20 Ağustos 2021 & $\begin{array}{l}\text { Tartışma - Kurum uygulamalarında etik iklim, itibar ve sürdürülebilirlik açısından, ürün-hizmet, } \\
\text { kurumun çekim gücü, kanun ve kodların en önem verilen değişkenler olduğu ortaya çıkmıştır. }\end{array}$ \\
\hline Makal & Kurumsal çalışmalarda bu alanlara ağırlık verilmelidir. Etik iklim, kurumsal itibar ve sürdürülebilirlik \\
\hline Araştır & $\begin{array}{l}\text { konularında akademik ve sosyal eğitim programları oluşturulması, benzer çalışmanın farklı zaman ve } \\
\text { hedef kitlelerle tekrar edilmesi önerilmektedir. }\end{array}$ \\
\hline
\end{tabular}

\section{ARTICLE INFO}

Keywords:

Ethic

Ethical climate

Corporate reputation

Corporate sustainability

Structural equality model.

Received 26 May 2021

Revised 11 August 2021

Accepted 20 August 2021

Article Classification:

Research Article

\section{ABSTRACT}

Purpose - Ethical climate, corporate reputation and corporate sustainability practices, which have a very important place in contemporary management approach, are the original basic resources of the enterprise and make it different from its competitors. The aim of the study is to scientifically reveal the interaction of these three issues and to raise awareness about the importance of this interaction in ensuring the sustainability of institutions.

Design/methodology/approach - Structural equation modeling (SEM), which models complex relationships between multiple variables, was used in the study. The research was carried out with simple random sampling, on 448 managers working in successful and reputable institutions in Turkey, using the survey method, one of the quantitative data collection methods. The data were analyzed with the Structural Equation Model SmartPLS application.

Findings - According to the results, it has been determined that ethical climate has a significant, positive impact on corporate reputation and sustainability, at the same time corporate reputation has an intermediary role in this effect.

Discussion - In terms of ethical climate, reputation and sustainability in corporate practices, it has been revealed that the most important variables are product-service, attraction power of the institution, laws and codes. Institutional studies should focus on these areas. It is recommended to establish academic and social training programs on ethical climate, corporate reputation and sustainability, and to repeat similar studies with different time and target groups.

*Bu çalışma, birinci yazarın, Doğuş Üniversitesi Lisansüstü Eğitim Enstitüsü İşletme Ana Bilim Dalı Doktora Programının 2020-2021 akademik yılında kabul edilen "Yöneticiler Açısından Etik İklimin Kurumsal Sürdürülebilirliğe Etkisinde Kurum İtibarının Rolü" isimli tezinden türetilmiştir. 


\section{GİRIŞ}

Günümüzde kurumlardan, ekonomik başarı yanında; paydaş beklentilerini karşılayan, çevreye ve topluma duyarlı, hesap verebilir, şeffaf bir yapı sağlamaları, sürdürülebilir olmaları beklenmektedir. Etik iklim, kurumsal itibar ve kurumsal sürdürülebilirlik uygulamaları bu hedeflere ulaşmayı sağlayan unsurların önde gelenlerindendir.

Kurumları rakiplerinden farklı kılan ögelerden birinin kurumdaki iklim olduğu ilk kez Gellerman (1973) tarafından belirtilmiştir (s. 74). Etik iklim, kurumun kararlarında dikkate alınan değerler, inançlar, ilkeler, kurallar, prosedürler, kodlar vb. gibi referans ve uygulamaların oluşturduğu ortamdır (Cullen, Parboteeah ve Victor, 2003, s. 127-141). Doğru yapılandırılmış bir etik iklim, çalışan bağlılığını, başarısını, motivasyonunu, doğru karar alma şansını; paydaşların kuruma saygısını, tercih gücünü; yönetimin kalitesini ve kurumun itibar algısını artırmaktadır (Barnett ve Schubert, 2002, s. 281). Etik iklimde oluşan bu kurumsal itibar, kaynak temelli yönetim yaklaşımında söz edilen, rekabette sürdürülebilir üstünlük sağlayan, nadir, taklit ve ikame edilemez bir maddi kaynaktır (Inglis, Clive ve Sammut, 2006, s. 935). 20. yy başlarında yönetimde temel fonksiyonlar planlama, organize etme, uygulama iken günümüzde kurum itibarı yöneticilerin öncelikli ele alması beklenen stratejik bir fonksiyon haline gelmiştir (Karatepe, 2008, s. 84). İtibar kazanma, alınan kararlar ve kurumsal uygulamalarda etik olunmasına bağlıdır. Kurumsal itibarın en önemli faydalarından biri, kuruma sürdürülebilirlik açısından stratejik bir rekabet avantajı kazandırmaktır (Bibri, 2008, s. 33).

Yaşamlarının devamlılığı, yani sürdürülebilir olmaları kurumların temel amaçlarındandır. Etik iklim ve itibar sürdürülebilirlik çabalarını destekleyen araçlardır. Sürdürülebilirlik, Dünya Çevre ve Gelişme Komisyonu'na göre (WCED) "gelecek nesillerin ihtiyaçlarını karşılama olanağını tehlikeye atmadan bugünün ihtiyaçlarının karşılanması" dır. Paydaş teorisi de, kurumsal sürdürülebilirliğin, kurumların tüm paydaşlarının çıkar ve beklentilerini gözetmesiyle mümkün olacağını savunur (Freeman, 1984). Sürdürülebilirlik uygulamaları, ekonomik, sosyal ve çevresel sorumluluğu, etiği göz önünde tutarak öne çıkaran faaliyetlerden oluşmakta, bunlara ilişkin performansların başarısıyla doğru orantılı olarak gelişmektedir. Söz konusu uygulamaların, verimlilik, düşük maliyet, düşük risk, çevreye katkı, inovasyon, pazar değeri artışı, paydaş sadakati, itibar artışı, rekabet avantajı gibi faydaları bulunmaktadır (Kuşat, 2012, s. 239)

Yukarıdaki açıklamalardan görüldüğü gibi üç konudan her birinin uygulanması diğer konuları etkilemektedir. Kapitalizm ve bireyi merkeze alan yeni dünya düzeni, doğal kaynakların aşırı tüketimine, çevre kirliliğine, adaletsiz paylaşıma, yolsuzluğa sebep olmaktadır. Bu sorunlarla mücadele etmede etik iklim zemininde doğru ve başarılı uygulamalarla itibar kazanmanın, kurumsal sürdürülebilirlik uygulamalarını gerçekleştirmenin kalııı başarıyı ve sürdürülebilirliği beraberinde getireceği öngörülmektedir.

Etik iklimin kurumsal itibar ve kurumsal sürdürülebilirliğe etkisi konusunu inceleyen bu çalışmanın alan yazın taramasında üç konunun bir arada incelendiği çalışmalara rastlanmadığından, bu araştırmanın özgün bir çalışma olduğu söylenebilir. Bu sebeple fikir vermesi açısından, konuların farklı ikili kombinasyonları ve yakın konulu diğer araştırmalar incelenmiş ve açıklamaları ilerleyen bölümlerde verilecek çoğu araştırmanın bu çalışma öngörüsünü desteklediği görülmüştür. Bu noktadan hareketle, araştırmanın amacı etik iklim, kurumsal itibar ve sürdürülebilirliğin aynı anda etkileşimini incelemek, bu etkileşimin önemi hakkında farkındalık yaratarak uygulanmasını sağlamak, böylece oluşacak güçlü kurumlarla, kurumsal, toplumsal ve doğal hayat arasında sağlıklı bir bağ kurulmasına katkı sunmaktır.

\section{KAVRAMSAL ÇERÇEVE}

Etik iklim, kurumsal itibar ve kurumsal sürdürülebilirlik uygulamaları, kurumların güçlü olabilmesi için gerekli yönetim araçlarıdır. İtibarlı ve sürdürülebilir bir kurum hedefi, etik iklim ortamında gerçekleştirilebilir. Her biri, diğerinin bir açıdan sebebi, başka bir açıdan sonucu konumunda olan üç konu, bu bölümde detaylandırılarak açıklanacaktır.

\subsection{Etik İklim}

Etik, doğru veya yanlış davranışla ilgili teorik alan, ahlak ise davranışın pratik, uygulama alanıdır (Pehlivan, 2001, 74). Bir sınav sistemine benzeyen etik alanda doğrular, yanlışlar, çıkar çatışmaları ve bunlara ilişkin 
seçimler bulunmaktadır. Ahlaki davranış, bu etik alanda doğru kararlar vermek için özgür irade ve bilinçle, çıarlara rağmen, evrensel doğruya yönelişi hedefleyen bir davranıştır (Gürsoy, 2015, s. 24-26).

İş Etiği, çalışma hayatında neyin doğru neyin yanlış olduğuna dair inançlara dayanan kurallar, ilkeler (Demir, 2006, s. 2), yönetmelikler, etik kodlar, standartların (Ussahawanitchakit, 2011, s. 4) tümüdür. İş hayatında alınan kararlarda bu kural ve ilkeler çalışanlara yol gösterir (Özgener, 2002, s. 177).

Etik iklim, yönetim kademesinden başlayarak kurum işleyişini etkileyen; kurum kültürü, etik anlayışı, kuralları, etik kodları ile şekil bulan; çalışan ve diğer paydaşlar tarafından algılanan kurum ortamıdır. Kurumlardaki etik iklim sayesinde etik karar alınması, verimlilik, sosyal sorumluluk, performans, çalışan memnuniyet ve bağlılık artışı ile işten ayrılmaların azalması sağlanabilir (Aktaran; Elçi ve Alpkan, 2006, s. 143). Ayrıca etik iklim güven ortamı sağlar. Güven olmayan olumsuz bir iklimden kurumlar zarar görebilir (Dinçer, 2003, s. 275).

\subsubsection{Etik İklimin Boyutlar}

Victor ve Cullen 1988 yılındaki çalışmasında, etik iklimin boyutlarını ortaya koymuşlardır. Burada temel olarak "etik kriter"ler başlı̆ğ altında egoizm, yardımseverlik ve ilkelilik alt boyutları; "analiz alanı" başlı̆ğ altında bireysel, kurumsal ve evrensel analiz boyutları bulunmaktadır. Bunların kesişimlerinden kişisel çıkar, arkadaşlık, kişisel ahlak; kurum çıkarı, takım çıarı, kurumsal kural ve prosedürler; verimlilik, sosyal sorumluluk ile kanun ve mesleki kodlar olmak üzere dokuz iklim türü ortaya çıkmıştır.

Victor ve Cullen etik iklim algısını tespit etmek için alanda en yetkin olan ve yaygın kullanılan Etik İklim Ölçeğini geliştirmişlerdir (Victor ve Cullen, 1987, 1988; Cullen vd., 1993; Fritzsche, 2000, s. 129). Victor ve Cullen (1988, s.112), bu ölçeği kullanarak yaptıkları bir araştırmanın faktör analizinde dokuz olan etik iklim boyutunu beş boyuta indirmişlerdir. Bunlar; araçsallık, başkalarının iyiliğini isteme, bağımsızlık, kurallar ile kanun ve kodlardır (Tablo 1)

Tablo 1. Etik İklimin Beş Boyutu

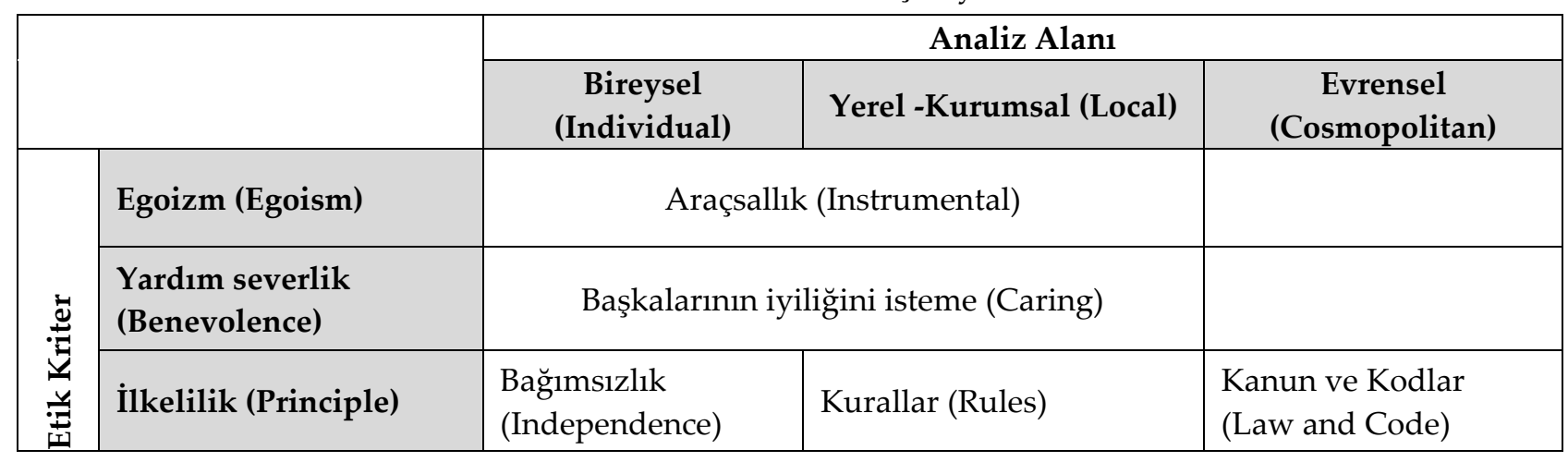

Kaynak: (Victor ve Cullen, 1987, 1988; Neubaum vd., 2004).

\subsection{Kurumsal İtibar}

Kurumun itibarı, bir kurumun tüm iç ve dış paydaşların, kuruma ait algılarının (Leaniz ve Bosque, 2013, s. 541) ya da değerlendirmelerinin tamamıdır (Gotsi ve Wilson, 2001, s. 29). Paydaşların kurum hakkındaki algısının yansıması olan itibar değeri, bir kurumun, nadir, ikame edilemez, taklit edilemez, en önemli rekabet avantajlarından biridir (Türk ve Güven, 2007, s. 89; Musteen vd., 2010, s. 498; Inglis, Clive ve Sammut, 2006, s. 935). Ancak güçlü bir itibara sahip kurum başarılı olmakta ve yaşam süresi uzun olabilmektedir (Çiftçioğlu, 2009, s. 4-5, 9; Karaköse, 2007, s. 3; Dörtok, 2004, s. 63; Tonus ve Tez, 2013, s. 1). İtibar yönetimi, kurum hedeflerine ulaşma, olumlu imaja sahip olma ve bunu koruma sürecidir (A. Okay ve A. D. Okay, 2005, s. 454).

İtibar, nitelikli insan kaynağı çekmede, gelecekle ilgili belirsizlik riskini azaltmada (Akdoğan ve Cingöz, 2009, s. 11) çalışan performansını artırmada, personel devir hızını azaltmada, maliyeti azaltmada, verimliliği ve piyasa değerini artırmada (Willard, 2005, s. 59), ürün ve hizmetlere olumlu psikolojik değer katmada, daha fazla kitleye ulaşmada, fiyat duyarlılı̆̆ının azalmasında kuruma katkı sağlamaktadır (Çiftçioğlu, 2009, s. 1112; Okay ve Okay, 2005, s. 471; Özpınar, 2008, s. 73). 


\subsubsection{Kurumsal İtibarn Boyutlarn}

Fombrun ve Shanley (1990), farklı kurum ve paydaşlar için farklı itibar boyutlarının daha fazla önemli olabilmesine karşın, genel olarak kurum itibarının çok önemli olduğunu belirtmiştir (s. 252-254). Kurumsal itibarın boyutları hakkında birçok görüş olmasına rağmen, bu çalışma kapsamında Charles Fombrun'ın arkadaşlarıyla yaptığı çalışmada yer alan altı boyut ve bunlardan oluşan ölçek kullanılmıştır (Fombrun vd., 1999). Bu boyutlar itibarı doğrudan etkileyen, ürün ve hizmet, vizyon ve liderlik, çalışan kalitesi ve çalışma ortamı, duygusal çekicilik, kurumsal sosyal sorumluluk ve finansal performanstır.

\subsection{Kurumsal Sürdürülebilirlik}

Sürdürülebilirlik, kalıcı refah sağlamak için ekonomik, çevresel ve sosyal konuların birlikte düşünülmesi gerektiği bütüncül bir yaklaşımdır (McGill University, 2018, s. 1). Temel konuları adaletsiz gelir dağılımı, yolsuzluk, işsizlik, açlık, yoksulluk, ayrımcılık gibi ekonomik ve sosyal sorunlar ile nüfus artışı, doğal kaynakların tüketimi, çevre kirliliği ve küresel ısınma gibi çevresel problemlerdir. Bir kurumun, mevcut ve potansiyel tüm paydaşlarının ihtiyaçlarını karşılayabilme olanağını kesintiye uğratmadan ve tehlikeye atmadan sağlanan kalkınma, kurumsal sürdürülebilirlik olarak ifade edilir (Dyllick ve Hockerts, 2002, s. 131).

Sürdürülebilirlikle ilgili üç temel yaklaşım bulunmaktadır. Birincisi, sürdürülebilirliğin çevresel konular olarak ele alındığı yaklaşımdır. İkincisi, literatürde yer alan "Üç $\mathrm{P}^{\prime}$ (kar, insan, gezegen- profit, people, planet) ve "Üçlü Raporlama Sistemi" (TBL-Triple bottom line) ifadeleri ile açıklanan yaklaşımdır. Üçüncüsünde ise iş sürekliliği ele alınmaktadır (Asif vd., 2011, s. 354). Bu çalışmada ekonomik, sosyal ve çevresel boyutların yer aldığı ikinci yaklaşım temel alınmıştır.

Sanayi Devrimi ve dünya savaşları sonrasında dünyadaki ekonomik refahın artışı ile birlikte nüfus artışı, kentleşme doğal kaynakların hızla tüketilmesine, çevre kirliliğine, enerji kaynaklarının hızlı tüketimine, çalışan haklarının göz ardı edilmesi gibi sorunlara yol açmıştır (Özmehmet, 2008, s. 2). 1960'l1 yıllardan itibaren, dünyanın önde gelen kurumları çevre sorunlarına çözüm arayışı ile ilgili aktif çalışmalarda bulunmuşlardır (Young ve Tilley, 2006, s. 403). 1987' de Brundtland veya Ortak Geleceğimiz Raporu (WCED, 1987), 1992'de "Rio Deklarasyonu" ve "Gündem 21" aksiyon planları (Sezer Özcan, s.767. Erişim Tarihi: 29.09.2020), 2015'de “Birleşmiş Milletler Sürdürülebilir Kalkınma için 2030 Gündemi” (Birleşmiş Milletler Raporu, 2016) ve 2019'da Avrupa Birliği tarafından duyurulan Avrupa Yeşil Anlaşması (European Green Deal) bunların en önemli örneklerindendir. Bunlarla, kaynakları verimli kullanma, biyoçeşitliliği koruma, kirliliği azaltma, şeffaf yönetim ve yönetişim, ortak hareketle hedeflere ulaşma sağlanmaya çalışılmıştır. BM Sürdürülebilir Kalkınma Hedefleri'ne her yıl dünyanın içinde bulunduğu duruma göre yeni konular (örn. 2020 Covit-19 salgını) eklenmektedir.

Güngör (2019) sürdürülebilirliğin öneminin henüz yeteri kadar kavranamadığını, ancak toplumsal olarak konu hakkındaki bilincin artmasıyla paydaşların da beklentilerinin artacağını belirtmiştir (s. 2077, 2081). Kurumlar, sürdürülebilirlik faaliyetlerini gerçekleştirerek; kaynak kullanımında verimlilik, düşük maliyet, düşük risk, çevresel değer yaratma, inovatif kurum yetkinliği oluşturma, pazar değerlerini artırma, paydaş sadakati oluşturma, kurum itibarı artışı sağlama, rekabet üstünlüğü elde etme, toplumsal refaha katkıda bulunma gibi faydalar sağlamış olurlar.

\subsubsection{Kurumsal Sürdürülebilirliğin Boyutlarn}

Kurumsal Sürdürülebilirliğin ekonomik, sosyal ve çevresel olmak üzere üç farklı boyutu bulunmaktadır (Özmehmet, 2008, s. 3). Kurumların sürdürülebilirlik stratejilerini gerçekleştirebilmeleri ancak bu üç boyutun aynı zamanda bütüncül bir yaklaşımla ele alınmasıyla sağlanabilir.

Ekonomik sürdürülebilirlik, dünyadaki tüm birey ve toplulukların ihtiyaçlarını karşılamaları için finansal ve diğer kaynaklara erişerek, finansal konular üzerinden, uzun vadeli bir devamlılığın gerçekleştirilmesi demektir (Tepe Küçükoğlu, 2014, s. 21). Kurumların şeffaf yönetilmeleri, yolsuzluk karşıtı önlemler almaları, giderleri ve enerji kullanımını azaltarak verimliliği artırmaları, küresel ekonomiye uyum ve entegrasyon sağlamaları (ortaklık vs), yeni iş alanları oluşturma ve bu faaliyetlerle ilgili raporlar hazırlayıp ilgililerle paylaşmaları ekonomik sürdürülebilirliğe katkı sunacaktır (Mimms, 2010, s. 12).

Sosyal sürdürülebilirlik kavram olarak kurumların uzun süre varolabilme, yerel ve küresel hedeflerini gerçekleştirebilme ve güncel siyasi konulara yanıt verme amacıyla ortaya çıkmıştır (Colantonio, 2009, s. 870). 
Sosyal sürdürülebilirlik, bugünkü ve gelecekteki nesilleri yetenek, sağlık, ihtiyaçlar açısından desteklemek, toplum içinde sağliklı iletişim kurup, bu sistemi yaşatmak olarak tanımlanmıştır (WACOSS - Western Australian Council of Social Services'den aktaran; Tuna, 2014, s. 15).

İklim değişikliği, küresel ısınma, kara ve deniz ekosistemindeki bozulmalar, doğal enerji kaynaklarının azalması, doğal kaynakların adil dağılımını zorlayan nüfus artışı çevresel anlamda çözüm bekleyen sorunlardır (Gözükara, 2019, s. 12-13). Çevresel sürdürülebilirlik, ihtiyaçların karşılanması için kullanılan doğal kaynakları korumak, zararlı atıkları minimize ve bertaraf etmek gibi çalışmalarla sürdürülebilirliğe katkıda bulunmayı hedeflemektedir (Küçükoğlu, 2014, s. 22).

Kurumların sürdürülebilirlik uygulamalarının başarıyla sonuçlanması için izlenmesi ve raporlanması gerekmektedir. Bu uygulamalara ilişkin performansların ölçülebilmesi için kendi kaynaklarından (her türlü ekonomik, sosyal, çevresel uygulamayı izleme ve değerlendirme raporları); dış kaynaklardan (GRI, Birleşmiş Milletler Küresel İlkeler Sözleşmesi, OECD İlkeleri vb); dış kurumların endekslerinin (Dow Johns endeksi, BİST Endeksi vb.) gerçekleştirdiği ölçümlerden faydalanılmaktadır.

\section{YÖNTEM}

\subsection{Araştırma Modeli ve Hipotezler}

Değişkenler arasında nedensellik ya da etkileşimi ortaya çıkaran açıklayıcı türdeki bu araştırmada, nicel araştırma yöntemlerinden ilişkisel tarama modeli benimsenmiştir. İlişkisel tarama modeli, iki veya daha fazla değişken arasındaki değişimin varlığını ve derecesini belirlemeyi hedefler (Karasar, 2009). Bu çalışmada etik iklim bağımsız değişkeninin, kurum itibarı ve sürdürülebilirlik bağımlı değişkenlerini nasıl etkilediği, aralarındaki etkileşimin/ilişkilerin nasıl olduğu ve kurum itibarının bağımlı, bağımsız değişken arasındaki aracı rolü araştırılmıştır. Araştırmanın modeli aşağıda, Şekil 1'de yer almaktadır:

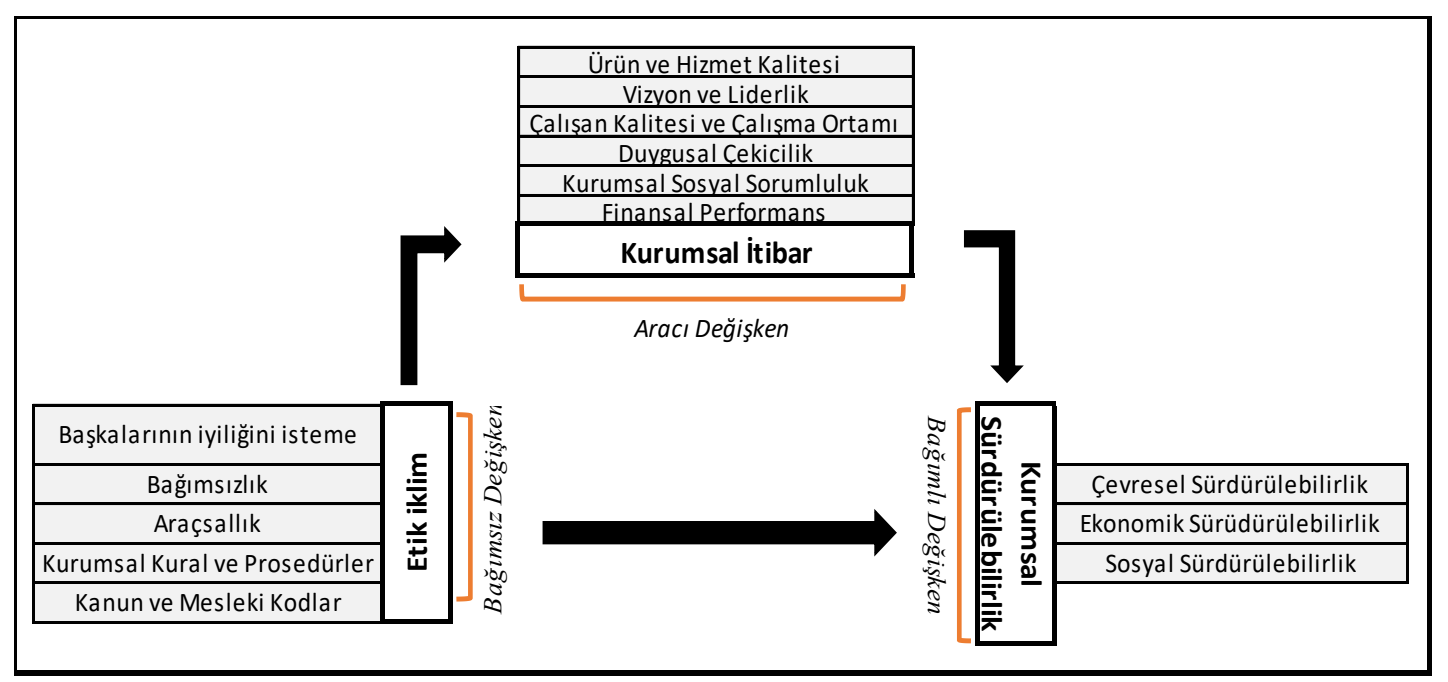

Şekil 1. Yöneticiler Açısından Etik İklimin Kurumsal Sürdürülebilirlik Uygulamalarına Etkisinde Kurum İtibarının Aracı Rolü

Çok boyutlu değişkenlerin yer aldığı araştırmalarda yönetim kolaylığı sağlayan değişkenlerin 2. düzeye (second order) çekilmesiyle, alt boyutlar yerine ana değişkenler üzerinden hipotezler oluşturularak araştırma yapılmıştır.

Araştırmanın üç ana konusu olan etik iklim, kurumsal itibar ve sürdürülebilirliğin bir arada olduğu, aynı anda etkileşiminin araştırıldığı bir çalışmaya daha önce yapılan araştırmalarda rastlanılamamıştır. Hipotezler bu boşluğu doldurma amacıyla özgün olarak oluşturulsa da literatür taramasından kavramsal ilişki taşıyan ikili, üçlü kombinasyonlu araştırmalardan da faydalanılmıştır. Araştırma hipotezleri aşağıda yer almaktadır:

H1: Yöneticiler açısından etik iklimin kurumsal sürdürülebilirlik uygulamalarına etkisi vardır.

H2: Yöneticiler açısından etik iklimin kurumsal itibara etkisi vardır.

H3: Yöneticiler açısından kurumsal itibarın kurumsal sürdürülebilirliğe etkisi vardır

H4: Yöneticiler açısından etik iklimin kurumsal sürdürülebilirlik uygulamalarına etkisinde kurum itibarının aracı rolü vardır. 
Model aracı değişkenli olduğu için Baron ve Kenny'nin (1986, s. 1176) aşağıdaki dört aşamalı model kontrolü de yapılmaktadır:

1. Bağımsız değişken ile bağımlı değişken arasında, $\% 5$ anlamlılık düzeyi için $p<0.05, t>1.96$ şartı sağlandığında istatistiki açıdan anlamlı bir ilişki vardır.

2. Bağımsız değişken ile aracı değişken arasında \%5 anlamlılık düzeyi için $p<0.05, t>1.96$ şartı sağladığında istatistiki açıdan anlamlı bir ilişki vardır.

3. Aracı değişken ile bağımlı değişken arasında \%5 anlamlılık düzeyi için $p<0.05, t>1.96$ şartı sağladığında istatistiki açıdan anlamlı bir ilişki vardır.

4. Bağımsız değişken ile bağımlı değişken arasındaki ilişkide, modele dahil edilen aracı değişkenine bağlı olarak, bağımsız değişken ile bağımlı değişken arasındaki ilişkinin istatistiksel olarak anlamsızlaşması (tam aracı etki) veya bağımsız değişkenin bağımlı değişken üzerindeki etkisinin öncekine göre azalması (kısmi aracı etki) gerekir.

\subsection{Evren ve Örneklem}

Türkiye' nin itibarlı şirketlerine ait evreni yansıtacak bir veriye TÜIK'te ulaşılamadığından, araştırmanın hedef kitlesini, kendi sektörlerinde itibar ve başarılarının bağımsız güvenilir araştırmalardan (Fortune 500 Türkiye, Bilişim 500, Capital 500, En Başarılı Finans Kurumları vb) tespit edildiği Türkiye'nin önde gelen kurumlarının yöneticileri (CEO, genel müdür, genel müdür yardımcısı, işletme fonksiyon, birim yöneticisi vb.) oluşturmuştur.

Araştırma, evreni temsil gücü yüksek, eşit seçilme olasılığına sahip elemanların olduğu, sık kullanılan olasılıklı basit tesadüfi örnekleme yöntemi (Saruhan ve Özdemirci, 2016, s. 202) ile yapılmıştır. Örnek kütle sayısını için sosyal bilimler araştırmalarında farklı evrenler için kabul edilebilir asgari örneklem büyüklükleri çalışmasından faydalanılmıştır (Yazıcıoğlu ve Erdoğan, 2004, s. 50). Bu çalışmaya göre 100 milyonun üzerine çıkan bir evrende bile 384 kişinin \%95 güvenilirlik seviyesinde evreni temsil ettiği belirtilmektedir. Bu çalışma için 469 anket doldurtulmuş, düzenlemeler sonrası net 448 anket üzerinden analiz yapılmıştır. Bu sebeple araştırmanın örnekleminin evreni temsil ettiği söylenebilir.

\subsection{Veri Toplama Aracı}

Nicel araştırma yöntemlerinden anket kullanılarak yapılan araştırma için Doğuş Üniversitesi Etik Kurulu tarafından 19.10.2020 tarih ve 2020/26 sayı no.lu “Etik Kurulu İzni” verilmiştir.

Araştırmada yer alan Etik iklim, kurumsal itibar ve sürdürülebilirlik konularına ait birçok makale ve tez incelenmiştir. Anket için aşağıda yer alan (Tablo 2) orijinal ölçekler ile bunların baz alındığı̆, güvenilirlik ve geçerlilik analizleri yapılmış yerel araştırmalar incelenerek anket oluşturulmuştur.

Tablo 2. Yararlanılan Ölçekler Tablosu

\begin{tabular}{|c|c|c|}
\hline Etik İklim & $\begin{array}{l}\text { Cullen, J.B., Victor, B. ve Bronson, J.W., The ethical climate questionnaire: An assessment } \\
\text { of its development and validity. Psychological reports, 73,667-674, } 1993\end{array}$ & Makale \\
\hline Etik İklim & $\begin{array}{l}\text { Victor Bart ve Cullen John B., The Organizational Bases of Ethical Work Climate, } \\
\text { Administrative Science Quarterly, } 1988\end{array}$ & Makale \\
\hline Etik İklim & $\begin{array}{l}\text { Kaplan, M., Otel işletmelerinde etiksel iklim algılamaları ile örgütsel bă̆lılık arasındaki } \\
\text { ilişkinin analizi: Kapadokya örneği, Doktora Tezi, Selçuk Üniversitesi, SBE, Konya, } \\
2010 .\end{array}$ & $\begin{array}{l}\text { Doktora } \\
\text { Tezi }\end{array}$ \\
\hline Kurumsal İtibar & $\begin{array}{l}\text { Fombrun, C, J., Gardberg, N. A. ve Sever, J.M., The Reputation Quatient:A Multi- } \\
\text { Stakeholder Measure of Reputation, The Journal of Brand Management, } 2000\end{array}$ & Makale \\
\hline Kurumsal İtibar & $\begin{array}{l}\text { Fombrun, C. J., Indices of Corporate Reputation: An Analysis of } \\
\text { Media Rankings and Social Monitors' Rattings, in: CRR, Jg.1, No:4, } \\
\text { 327-340, } 1998\end{array}$ & Makale \\
\hline Kurumsal İtibar & $\begin{array}{l}\text { Bozkurt, M., Kurumsal İtibar Yönetiminin Müşteri Değerlendirme Sürecine Yansıması Ve } \\
\text { Etkileri: Konaklama İşletmelerine Yönelik Bir Uygulama", Yayınlanmamış Doktora Tezi, } \\
\text { Balıkesir Üniversitesi Sosyal Bilimler Enstitüsü, Balıkesir., } 2011\end{array}$ & $\begin{array}{l}\text { Doktora } \\
\text { Tezi }\end{array}$ \\
\hline Kurumsal İtibar & 2020 Global Trends In Reputation (Reputationinstitute.com) & Rapor \\
\hline $\begin{array}{l}\text { Kurumsal } \\
\text { Sürdürülebilirlik }\end{array}$ & $\begin{array}{l}\text { Hahn, T., ve Scheermesser, M. Approaches to corporate } \\
\text { sustainability among german companies, Corporate Social Responsibility and } \\
\text { Environmental Management, 13(3), 150-165, } 2006\end{array}$ & Makale \\
\hline
\end{tabular}




\begin{tabular}{|l|l|l|l|}
\hline $\begin{array}{l}\text { Kurumsal } \\
\text { Sürdürülebilirlik }\end{array}$ & $\begin{array}{l}\text { Aksoy, Ç., Sürdürülebilirlik Performansının Değerlendirilmesine Yönelik Ölçek Önerisi ve } \\
\text { Türkiye'deki İşletmelerde Uygulaması. Yayınlanmamış Doktora Tezi. İstanbul: Marmara } \\
\text { Üniversitesi Sosyal Bilimler Enstitüsü, 2013 }\end{array}$ & $\begin{array}{l}\text { Doktora } \\
\text { Tezi }\end{array}$ \\
\hline $\begin{array}{l}\text { Kurumsal } \\
\text { Sürdürülebilirlik }\end{array}$ & $\begin{array}{l}\text { Tuna, Ö., Kurumsal sürdürülebilirlik yaklaşım ve uygulamalart: Kobi'lere Yönelik Bir } \\
\text { Araştırma. Afyon Kocatepe Üniversitesi, Sosyal Bilimler Enstitüsü, Doktora Tezi, } \\
2014\end{array}$ & $\begin{array}{l}\text { Doktora } \\
\text { Tezi }\end{array}$ \\
\hline
\end{tabular}

Anket "Etik İklim", "Kurum İtibarı" ve "Kurumsal Sürdürülebilirlik" temel bölümleri ile "Kişi ve Kurum Bilgileri" kısmı olmak üzere dört bölümden oluşmuştur. Etik iklim 26, kurumsal itibar 26, Kurumsal sürdürülebilirlik 54, kişisel ve kurumsal bilgiler 16 sorudan oluşmak üzere toplam 122 soru bulunmaktadır. Katılımcıların konu hakkında görüşlerini hassas ve tutarlı bir şekilde ölçmek amacıyla, 1 "kesinlikle katılmıyorum"dan 5 “kesinlikle katılıyorum"' a şeklinde sıralanan beşli likert ölçeği kullanılmıştır. Cevaplar, Sorular pilot çalışmalar ve geri bildirimlerle son haline getirilmiştir.

\subsection{Veri Analizi}

Çalışmada veri analizi temel olarak iki kısımda ele alınmıştır. Birinci kısım demografik verilerin ve anket cevaplarının yer aldığı temel, tanımlayıcı istatistiklerdir. Söz konusu analizler, daha sonraki bir çalışmada sunulacaktır. Bu çalışmanın veri analizi ise karmaşık modellerin istatistiki analiz yöntemlerinden Yapısal Eşitlik Modeli (YEM) ile gerçekleştirilmiştir. YEM yöntemi, birden fazla değişkenin arasındaki etkileşim ve ilişkinin açıklanmasını hedefleyerek (Sümer, 2000, sf 49; Polat, 2018, sf 5326), oluşturulan modelin doğrulanıp doğrulanmadığını test etmektedir (Çokluk vd., 2010). Çalışma için YEM'nin, PLS-SEM yöntemine bağlı, sosyal bilimciler tarafından sıkça kullanılan gelişmiş bir yazılım olan SmartPLS uygulaması tercih edilmiştir. Geleneksel yöntemlere göre üstünlükleri olması sebebi ile günümüzde sıkça kullanılmaktadır. YEM ve SmartPLS modeldeki değişken ölçeklerinin güvenirlik ve geçerliği ile modeldeki değişkenler arasındaki ilişkinin derece ve anlamlılık düzeyini aynı anda değerlendirebilmektedir (Bal vd., 2012). Yeniden örnekleme (Bootstrapping) yöntemi ile, geleneksel yöntemlere göre daha güvenilir sonuçlar elde edilmektedir (Preacher vd., 2007), karmaşık modelleri kolayca analiz edebilmekte, veri boyutunu azaltarak analizi sadeleştirebilmektedir (Feng vd.,2013, 1831). PLS-SEM, henüz geliştirilmemiş teorilerin bulunduğu keşifsel araştırmalar için en uygun yöntemlerdendir (Garson, 2016, sf 8 8).

YEM kapsamında ilk aşamada Araştırma Modeli Ön analizi yapılmaktadır. Bu analiz grubunda güvenilirlik ve geçerlilik analizleri bulunmaktadır. Güvenilirlik analizinde değişkenlerin güvenilirliği ile iç tutarlılık güvenilirliği analizi; geçerlilik analizinde, uyuşum geçerliliği ve ayırt edici geçerlilik analizleri yer almaktadır. Bundan sonra "Araştırma Modeli Yol Analizi" ile model analizine başlanmaktadır. Bu analiz altında; Araştırma Modeli Doğrusallık Analizi, İlişkilerin Anlamlılık Düzeyi Analizi, Açıklanan Varyans Analizi, Q2 Endojen Değişkenlerin Tahmin Gücü Analizi, Model Uygunluğunun Analizi, Araştırma Modeli Önemlerine Göre Performans Haritası Analizi (IPMA), Çoklu Grup Analizi (Multigroup Analysis) bulunmaktadır. Son aşamadaki Çoklu Grup Analizi demografik karşılaştırmaları içerdiğinden, demografik bilgilerin ele alınacağı belirtilen daha sonraki çalışmada bu konuya da detaylı olarak değinilecektir. Aşağıda bulgular kısmında YEM kapsamındaki analiz detaylı olarak açıklanmıştır.

\section{BULGULAR}

Bu kısımda demografik veriler sunulduktan sonra, araştırma veri analizinden söz edilecektir.

\subsection{Demografik Veriler}

Toplam 448 katılımcı ile gerçekleştirilen anket çalışmasında aşağıdaki demografik veriler elde edilmiştir: (Tablo 3): 
G. Ayral - N. Saracel 13/3 (2021) 2376-2395

Tablo 3. Araştırma Katılımcı Demografik Veriler Tablosu

\begin{tabular}{|c|c|c|c|}
\hline \multicolumn{4}{|c|}{ Katılımcı ile İlgili Bilgiler } \\
\hline Özellikler & & Frekans & Yüzde \\
\hline \multicolumn{4}{|c|}{ Kat1lımc1 Sayıs1 } \\
\hline & Toplam & 448 & $100 \%$ \\
\hline \multicolumn{4}{|c|}{ Kurumdaki Pozisyon } \\
\hline & Üst Kademe Yönetici & 160 & $36 \%$ \\
\hline & Orta Kademe Yönetici & 282 & $63 \%$ \\
\hline & Diğer & 6 & $1 \%$ \\
\hline & Toplam & 448 & $100 \%$ \\
\hline \multicolumn{4}{|c|}{ Çalıșilan Departman } \\
\hline & Ar-ge / İș Geliștirme & 8 & $2 \%$ \\
\hline & Bilgi Teknolojileri & 20 & $4 \%$ \\
\hline & İnsan Kaynakları-Eğitim & 28 & $6 \%$ \\
\hline & Muhasebe-Finans & 30 & $7 \%$ \\
\hline & Müşteri Hizmetleri & 17 & $4 \%$ \\
\hline & Satınalma-Lojistik-Tedarik & 34 & $8 \%$ \\
\hline & Satış-Pazarlama & 125 & $28 \%$ \\
\hline & Üretim-Mühendislik-Kalite & 28 & $6 \%$ \\
\hline & Üst Yönetim & 154 & $34 \%$ \\
\hline & Diğer & 4 & $1 \%$ \\
\hline & Toplam & 448 & $100 \%$ \\
\hline \multicolumn{4}{|c|}{ Kalite/Sürdürülebilirlik /Etik sizin sorumluluğunuzda mı? } \\
\hline & Evet & 96 & $21 \%$ \\
\hline & Hayır & 352 & $79 \%$ \\
\hline & Toplam & 448 & $100 \%$ \\
\hline \multicolumn{4}{|l|}{ Yaş } \\
\hline & $20-30$ & 42 & $9 \%$ \\
\hline & $31-40$ & 135 & $31 \%$ \\
\hline & $41-50$ & 207 & $46 \%$ \\
\hline & 51 ve üstü & 64 & $14 \%$ \\
\hline & Toplam & 448 & $100 \%$ \\
\hline \multicolumn{4}{|l|}{ Eğitim } \\
\hline & Yüksek lisans & 184 & $41 \%$ \\
\hline & Lisans & 264 & $59 \%$ \\
\hline & Toplam & 448 & $100 \%$ \\
\hline \multicolumn{4}{|c|}{ Medeni Durum } \\
\hline & Evli & 327 & $73 \%$ \\
\hline & Bekar & 121 & $27 \%$ \\
\hline & Toplam & 448 & $100 \%$ \\
\hline \multicolumn{4}{|c|}{ Çocuk Sahipliği } \\
\hline & Çocuğu var & 305 & $68 \%$ \\
\hline & Çocuğu yok & 142 & $32 \%$ \\
\hline & Toplam & 448 & $100 \%$ \\
\hline \multicolumn{4}{|l|}{ Cinsiyet } \\
\hline & Erkek & 270 & $60 \%$ \\
\hline & Kadın & 178 & $40 \%$ \\
\hline & Toplam & 448 & $100 \%$ \\
\hline
\end{tabular}

\subsection{Yapısal Eşitlik Modeli (YEM) Analizleri}

YEM analizleri, model ön analizi ve yol analizi olmak üzere iki başlık altında incelenmektedir. Bu analizler kullanılarak aşağıdaki bulgular elde edilmiştir:

\subsubsection{Araştırma Modeli Ön Analizleri}

Ön analizler güvenilirlik ve geçerlilik analizleridir.

1. Güvenilirlik Analizleri

a. Değişken güvenilirliği analizi: Bu analiz için Hair ve diğerlerinin (2010) önerdiği yöntem kullanılmıştır. VIF ve Dışsal Yük Tablosu'nda (Tablo 3) yükleri 0.40'tan küçük olan değişkenler analizden çıkarılmış, 0.70 
üzerindeki değişkenler korunmuştur. Yükleri 0.40 ile 0.70 arası değişkenlerin uyuşum geçerliliği (AVE >0.50) ve bileşik güvenilirlik (CR > 0.70) değerlerine bakılmıştır. Değişkenlere ait değerler, norm değerler içindeyse analiz kapsamında tutulmuş, değilse analizden çıkartılmıştır.

Tablo 3. VIF ve Dışsal Yük Tablosu (Varyans artış faktörü, VIF < 5 ), Dışsal Yük > 0.70

\begin{tabular}{|l|c|c|}
\hline Değişkenler & VIF & Dişsal Yük \\
\hline EiKanunKod1 & 3.176 & 0.899 \\
\hline EiKanunKod2 & 3.315 & 0.907 \\
\hline EiKanunKod3 & 2.307 & 0.860 \\
\hline EiKanunKod4 & 1.988 & 0.828 \\
\hline Eibagimsizlik1 & 1.366 & 0.902 \\
\hline Eibagimsizlik2 & 1.364 & 0.837 \\
\hline Eibakim1 & 2.964 & 0.829 \\
\hline Eibakim2 & 2.970 & 0.835 \\
\hline Eibakim3 & 2.909 & 0.847 \\
\hline Eibakim4 & 1.928 & 0.743 \\
\hline Eibakim5 & 1.979 & 0.783 \\
\hline Eibakim6 & 1.806 & 0.758 \\
\hline Eibakim7 & 1.414 & 0.614 \\
\hline Eikurallar1 & 2.840 & 0.864 \\
\hline Eikurallar2 & 3.029 & 0.880 \\
\hline Eikurallar3 & 2.669 & 0.844 \\
\hline Eikurallar4 & 2.894 & 0.868 \\
\hline Kiduygusalcekici3 & 2.316 & 0.934 \\
\hline Kiduygusalcekici4 & 2.316 & 0.939 \\
\hline Kifinans1 & 1.325 & 0.708 \\
\hline Kifinans3 & 2.069 & 0.878 \\
\hline Kifinans4 & 2.233 & 0.903 \\
\hline Kiisyeri1 & 1.922 & 0.867 \\
\hline Kiisyeri2 & 2.593 & 0.909 \\
\hline Kiisyeri3 & 2.029 & 0.850 \\
\hline Kiliderlik1 & 2.720 & 0.878 \\
\hline Kiliderlik2 & 2.191 & 0.905 \\
\hline Kiliderlik3 & 1.569 & 0.864 \\
\hline Kiliderlik4 & 2.476 & 0.826 \\
\hline Kisosyalsorumluluk1 & 2.960 & 0.871 \\
\hline Kisosyalsorumluluk2 & 2.218 & 0.829 \\
\hline Kisosyalsorumluluk3 & 1.748 & 0.732 \\
\hline Kisosyalsorumluluk4 & & 0.745 \\
\hline Kisosyalsorumluluk5 & 1.973 & 0.825 \\
\hline Kisosyalsorumluluk6 & \\
\hline
\end{tabular}

\begin{tabular}{|l|c|c|}
\hline Değişkenler & VIF & Dişsal Yük \\
\hline Kiurun1 & 3.421 & 0.869 \\
\hline Kiurun2 & 3.826 & 0.886 \\
\hline Kiurun3 & 2.158 & 0.803 \\
\hline Kiurun4 & 4.244 & 0.913 \\
\hline Kiurun5 & 3.513 & 0.893 \\
\hline cev10Surdurulebilirlik4.6 & 3.391 & 0.814 \\
\hline cev11Surdurulebilirlik4.7 & 3.096 & 0.789 \\
\hline cev1Surdurulebilirlik5.7 & 2.134 & 0.681 \\
\hline cev2Surdurulebilirlik5.9 & 2.553 & 0.707 \\
\hline cev3Surdurulebilirlik5.6 & 1.953 & 0.674 \\
\hline cev3Surdurulebilirlik5.8 & 2.873 & 0.743 \\
\hline cev4Surdurulebilirlik3.7 & 3.462 & 0.777 \\
\hline cev5Surdurulebilirlik3.9 & 3.615 & 0.796 \\
\hline cev6 Surdurulebilirlik3.11 & 2.762 & 0.754 \\
\hline cev7Surdurulebilirlik3.6 & 2.662 & 0.731 \\
\hline cev9Surdurulebilirlik4.8 & 2.856 & 0.754 \\
\hline eko10Surdurulebilirlik3.18 & 2.594 & 0.790 \\
\hline eko11Surdurulebilirlik3.12 & 2.103 & 0.744 \\
\hline eko12Surdurulebilirlik3.1 & 2.315 & 0.718 \\
\hline eko12Surdurulebilirlik3.17 & 2.597 & 0.787 \\
\hline eko15Surdurulebilirlik5.2 & 1.699 & 0.677 \\
\hline eko16 Surdurulebilirlik3.8 & 2.139 & 0.751 \\
\hline eko3Surdurulebilirlik3.22 & 4.510 & 0.830 \\
\hline eko4Surdurulebilirlik3.13 & 3.160 & 0.835 \\
\hline eko5Surdurulebilirlik3.15 & 2.731 & 0.792 \\
\hline eko6Surdurulebilirlik3.21 & 3.661 & 0.795 \\
\hline eko7Surdurulebilirlik3.23 & 2.121 & 0.745 \\
\hline eko8Surdurulebilirlik3.2 & 2.457 & 0.762 \\
\hline eko9Surdurulebilirlik3.16 & 3.147 & 0.833 \\
\hline sos1Surdurulebilirlik5.5 & 2.383 & 0.848 \\
\hline sos2Surdurulebilirlik5.4 & 2.183 & 0.838 \\
\hline sos3Surdurulebilirlik3.10 & 1.679 & 0.780 \\
\hline sos4Surdurulebilirlik5.1 & 1.354 & 0.638 \\
\hline sos5Surdurulebilirlik3.4 & 1.941 & 0.812 \\
\hline & & \\
\hline
\end{tabular}

b. İç tutarlılık analizi: Cronbach's Alpha, Bileşik Güvenilirlik (CR - Composite Reliability) değerleri üzerinden yapılmaktadır (Urbach ve Ahlemann, 2010). Bu değerlerin 0.70'den büyük olması gerekir. Araçsallık dışındaki değerler referans değerleri karşıladığından iç tutarlılığın sağlandığı tespit edilmiştir.

2. Geçerlilik Analizleri

a. Uyuşum geçerliliği: AVE (The Average Variance Extracted) değerlerinin 0.50 'den büyük olması beklenmektedir (Fornel ve Larcker, 1981; Falk ve Miller, 1992). Bu araştırma verilerine göre AVE değerleri > 0.50 olduğu için uyuşum geçerliliğinin olduğu görülmüştür (Tablo 4). Ölçek ön analizleri sonucunda "araçsallık" faktörünün normlara uymadığı belirlenmiş (Cronbach's Alpha'da $<0.70, C R$ 'da $<0.70$ ve AVE'de $<0.50$ olduğundan) analizden çıkartılmıştır. Bu haliyle diğer alt boyutların tümü norm değerleri karşıladığından analize dahil edilmiştir (Tablo 4). 
Tablo 4. İç Tutarlılık (Croncbach's Alpha), Bileşik Güvenilirlik (CR), Uyuşum Geçerliliği (AVE)

\begin{tabular}{|l|c|c|c|c|}
\hline Değişkenler & $\begin{array}{c}\text { Cronbach's } \\
\text { Alpha }\end{array}$ & rho_A & $\begin{array}{c}\text { Composite } \\
\text { Reliability }\end{array}$ & $\begin{array}{c}\text { Average Variance } \\
\text { Extracted (AVE) }\end{array}$ \\
\hline Bağımsızlık & 0.682 & 0.708 & 0.861 & 0.757 \\
\hline Başkalarının İyiliğini İsteme & 0.888 & 0.893 & 0.913 & 0.603 \\
\hline Duygusal Çekicilik & 0.86 & 0.86 & 0.934 & 0.877 \\
\hline ETİK İKLIM & 0.942 & 0.944 & 0.949 & 0.553 \\
\hline Ekonomik Sürdürülebilirlik & 0.944 & 0.945 & 0.951 & 0.601 \\
\hline Finansal & 0.778 & 0.811 & 0.872 & 0.696 \\
\hline KURUMSAL İTíBAR & 0.966 & 0.969 & 0.969 & 0.579 \\
\hline Kanun ve Kodlar & 0.897 & 0.898 & 0.928 & 0.764 \\
\hline Kurallar & 0.887 & 0.888 & 0.922 & 0.747 \\
\hline Liderlik & 0.874 & 0.879 & 0.914 & 0.728 \\
\hline Sosyal Sorumluluk & 0.892 & 0.902 & 0.917 & 0.65 \\
\hline Sosyal Sürdürülebilirlik & 0.844 & 0.858 & 0.89 & 0.619 \\
\hline SÜRDÜRÜLEBİLİRLIK & 0.968 & 0.969 & 0.971 & 0.533 \\
\hline Çevresel Sürdürülebilirlik & 0.921 & 0.922 & 0.933 & 0.56 \\
\hline Ürün ve Hizmet & 0.922 & 0.923 & 0.941 & 0.763 \\
\hline İşyeri & 0.848 & 0.852 & 0.908 & 0.766 \\
\hline
\end{tabular}

b. Ayırt Edici Geçerlilik: Ayırt Edici Geçerlilik başlığı altında iki analiz yapılmıştır;

i.Fornell-Larcker ayırt edici geçerlilik analizi: Bu aşamada ayırt edici geçerlilik için Fornell-Larcker analizi çıtısı olan korelasyon tablosu incelenmiştir. Analiz çıktısında diagonal değerlerin ait olduğu sütundaki diğer değerlerden daha büyük olması gerekir (Fornel ve Larcker, 1981). Tablo 5'te verilen sonuçlar incelendiği zaman modelin ayırt edici geçerliliği bulunduğu görülmektedir.

ii.The Heterotrait-Monotrait (HTMT) Analizi: Henseler ve diğerleri (2014), ayırt edici geçerlilikte FornellLacker yönteminin yeterince hassas olmadığından, Heterotrait-Monotrait (HTMT) analizinin yapılmasını önermiş̧ir. Korelasyonların referansı "HTMT; $\leq 0.90$ ” dir. Tablo 6' da görüldüğü gibi HTMT analizi değerleri $\leq$ 0.90 olduğu için modelin ayırt edici geçerliliği bulunduğu görülmektedir.

Tablo 5. Fornell-Larcker Ayırt Edici Geçerlilik Analizi - Aracı Değişkenli

\begin{tabular}{|c|c|c|c|c|c|c|c|c|c|c|c|c|c|}
\hline Değişkenler & 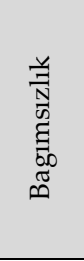 & 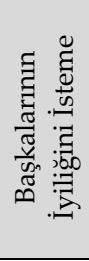 & 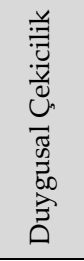 & 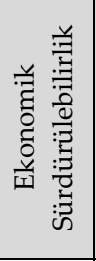 & 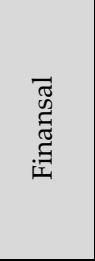 & 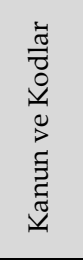 & 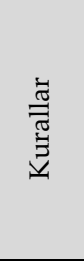 & 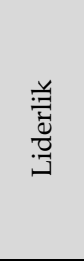 & 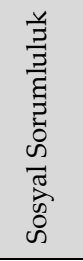 & 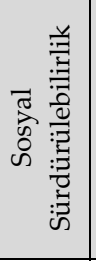 & 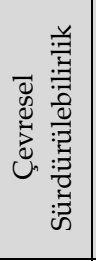 & 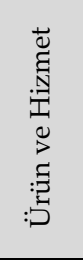 & $\begin{array}{l}\overrightarrow{0} \\
\overrightarrow{\omega^{n}}\end{array}$ \\
\hline Bagımsızlık & 0.87 & & & & & & & & & & & & \\
\hline $\begin{array}{l}\text { Başkalarının } \\
\text { İyiliğini İsteme }\end{array}$ & 0.148 & 0.776 & & & & & & & & & & & \\
\hline $\begin{array}{l}\text { Duygusal } \\
\text { Çekicilik }\end{array}$ & 0.095 & 0.719 & 0.936 & & & & & & & & & & \\
\hline $\begin{array}{l}\text { Ekonomik } \\
\text { Sürdürülebilirlik }\end{array}$ & 0.056 & 0.682 & 0.65 & 0.775 & & & & & & & & & \\
\hline Finansal & 0.089 & 0.594 & 0.626 & 0.657 & 0.834 & & & & & & & & \\
\hline Kanun ve Kodlar & 0.109 & 0.701 & 0.614 & 0.645 & 0.507 & 0.874 & & & & & & & \\
\hline Kurallar & 0.122 & 0.671 & 0.567 & 0.602 & 0.518 & 0.789 & 0.864 & & & & & & \\
\hline Liderlik & 0.108 & 0.697 & 0.727 & 0.753 & 0.806 & 0.574 & 0.577 & 0.853 & & & & & \\
\hline Sosyal Sorumluluk & 0.081 & 0.64 & 0.696 & 0.743 & 0.681 & 0.605 & 0.584 & 0.79 & 0.806 & & & & \\
\hline $\begin{array}{l}\text { Sosyal } \\
\text { Sürdürülebilirlik }\end{array}$ & 0.076 & 0.627 & 0.629 & 0.83 & 0.615 & 0.593 & 0.588 & 0.679 & 0.75 & 0.787 & & & \\
\hline $\begin{array}{l}\text { Çevresel } \\
\text { Sürdürülebilirlik }\end{array}$ & 0.051 & 0.658 & 0.639 & 0.858 & 0.621 & 0.623 & 0.601 & 0.727 & 0.784 & 0.869 & 0.749 & & \\
\hline Ürün ve Hizmet & 0.098 & 0.717 & 0.799 & 0.717 & 0.721 & 0.693 & 0.612 & 0.804 & 0.737 & 0.665 & 0.694 & 0.874 & \\
\hline İşyeri & 0.057 & 0.687 & 0.751 & 0.711 & 0.739 & 0.535 & 0.51 & 0.833 & 0.727 & 0.656 & 0.675 & 0.75 & 0.875 \\
\hline
\end{tabular}


Tablo 6. HTMT Ayırt Edici Geçerlilik Analizi (Aracı Değişkenli)

\begin{tabular}{|c|c|c|c|c|c|c|c|c|c|c|c|c|c|}
\hline Değişkenler & 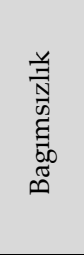 & 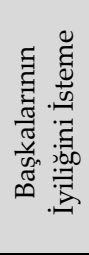 & 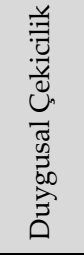 & 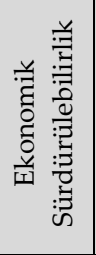 & 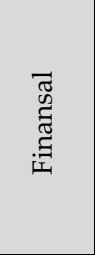 & 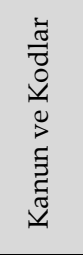 & $\begin{array}{l}\text { పే } \\
\stackrel{\widetilde{J}}{\Xi} \\
\underline{\Xi}\end{array}$ & 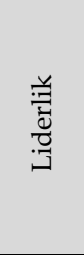 & 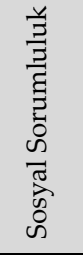 & 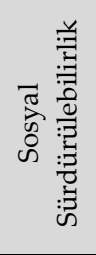 & 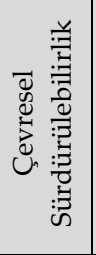 & 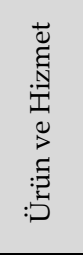 & 芯 \\
\hline \multicolumn{14}{|l|}{ Bagımsızlık } \\
\hline $\begin{array}{l}\text { Başkalarının } \\
\text { İyiliğini İsteme }\end{array}$ & 0.192 & & & & & & & & & & & & \\
\hline $\begin{array}{l}\text { Duygusal } \\
\text { Çekicilik }\end{array}$ & 0.13 & 0.822 & & & & & & & & & & & \\
\hline $\begin{array}{l}\text { Ekonomik } \\
\text { Sürdürülebilirlik }\end{array}$ & 0.078 & 0.743 & 0.824 & & & & & & & & & & \\
\hline Finansal & 0.122 & 0.709 & 0.756 & 0.757 & & & & & & & & & \\
\hline Kanun ve Kodlar & 0.137 & 0.779 & 0.7 & 0.703 & 0.891 & & & & & & & & \\
\hline Kurallar & 0.153 & 0.754 & 0.649 & 0.658 & 0.623 & 0.882 & & & & & & & \\
\hline Liderlik & 0.149 & 0.788 & 0.815 & 0.73 & 0.868 & 0.649 & 0.754 & & & & & & \\
\hline Sosyal Sorumluluk & 0.111 & 0.703 & 0.78 & 0.802 & 0.8 & 0.664 & 0.646 & 0.887 & & & & & \\
\hline $\begin{array}{l}\text { Sosyal } \\
\text { Sürdürülebilirlik }\end{array}$ & 0.106 & 0.707 & 0.725 & 0.717 & 0.742 & 0.672 & 0.671 & 0.777 & 0.854 & & & & \\
\hline $\begin{array}{l}\text { Çevresel } \\
\text { Sürdürülebilirlik }\end{array}$ & 0.105 & 0.724 & 0.72 & 0.718 & 0.729 & 0.687 & 0.665 & 0.812 & 0.823 & 0.879 & & & \\
\hline Ürün ve Hizmet & 0.128 & 0.788 & 0.816 & 0.749 & 0.844 & 0.762 & 0.675 & 0.886 & 0.799 & 0.742 & 0.775 & & \\
\hline İşyeri & 0.091 & 0.789 & 0.817 & 0.754 & 0.802 & 0.61 & 0.584 & 0.859 & 0.818 & 0.757 & 0.762 & 0.846 & \\
\hline
\end{tabular}

\subsubsection{Araştırma Modeli Yol Analizi}

Araştırma Modeli Yol Analizi, Hair ve diğerlerinin (2010) önerdiği aşağıdaki analiz sırasına göre yapılmıştır:

1. Araştırma Modeli Doğrusallık Analizi

Araştırma modelinin doğrusallık analizi için varyans artış faktörü (VIF) değerlerinin oluşturulması gerekmektedir. Değişkenlere ait VIF değerlerinin $5^{\prime}$ ten büyük olması (VIF $\geq 5$ ) araştırma modelindeki bağımsız değişkenler arasında yüksek korelasyon olduğunun ifadesidir (Hair, Black, Babin ve Anderson, 2010) ve bu sebeple araştırma modeli değişkenlerine ait VIF değerlerinin 5 'ten küçük olması beklenir (referans: VIF < 5). Araştırma modeli kapsamındaki değişken VIF değerleri 5 'ten küçük tespit edilmiştir (Tablo 3). Böylece değişkenler arasında doğrusallık problemi olmadığ ${ }_{1}$ kabul edilmiştir.

2. Araştırma Modeli Yol Analizi: Anlamlılık Düzeyi Analizi

Bu analizde araştırma modeli yol analizi çıkarılır (Şekil 2). Bu yol analizi kapsamındaki ilişkilerin anlamlılık düzeyi analiz edilir. Referans değeri " $p<0.05$ " dir. 


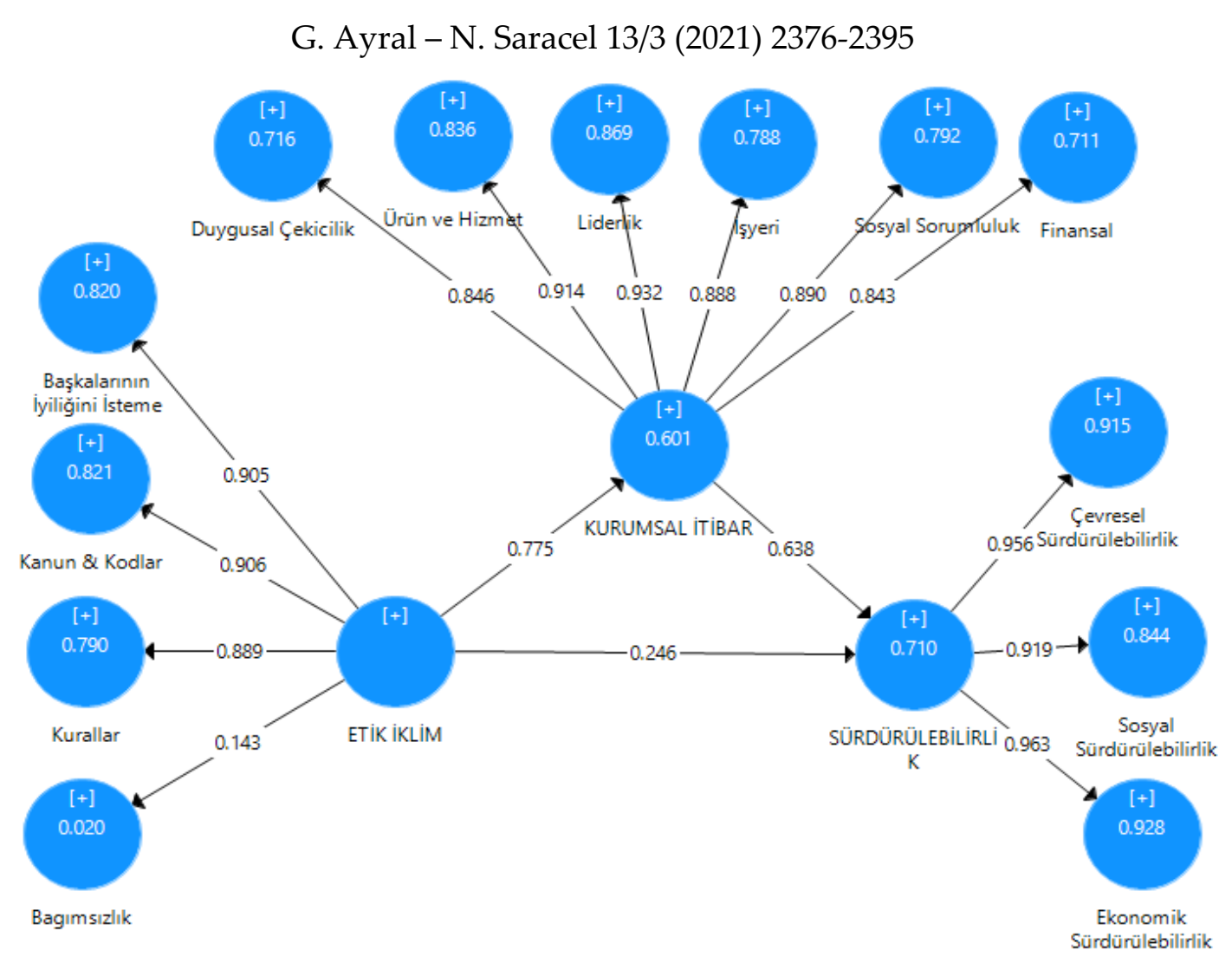

Şekil 2 Araştırma Modelinin Yol Analizi $(\mathrm{p}<0.05)$

Şekildeki daireler değişken alt boyutları; daire içindeki sayılar ilgili değişkene ait $\mathrm{R}^{2}$ değerini; daireler arasındaki oklar modeldeki yolları, yolların üzerindeki sayısal değerler de $\mathrm{O}$ (original sample) değerini yani $\beta$ katsayısını göstermektedir. Yol analizi kapsamındaki ilişkilerin anlamlılık düzeyine bakmak için aşağıda yer alan bundan sonraki analiz adımlarını takip etmek gerekmektedir.

3. Açıklanan Varyans Analizi R2 ve Bootsrapping

$\mathrm{Bu}$ analiz sonucunda alt faktörlerin bulunan değerlerinin anlamlı olup olmadığına bakılır (Tablo 7).

Tablo 7. Açıklanan Varyans Analizi

\begin{tabular}{|c|c|c|}
\hline Değişkenler & R Square & R Square Adjusted \\
\hline Bagımsızlık & 0.020 & 0.018 \\
\hline Başkalarının İyiliğini İsteme & 0.820 & 0.819 \\
\hline Duygusal Çekicilik & 0.716 & 0.716 \\
\hline Ekonomik Sürdürülebilirlik & 0.928 & 0.928 \\
\hline Finansal & 0.711 & 0.710 \\
\hline KURUMSAL İTIBAR & 0.601 & 0.600 \\
\hline Kanun ve Kodlar & 0.821 & 0.821 \\
\hline Kurallar & 0.790 & 0.790 \\
\hline Liderlik & 0.869 & 0.869 \\
\hline Sosyal Sorumluluk & 0.792 & 0.791 \\
\hline Sosyal Sürdürülebilirlik & 0.844 & 0.843 \\
\hline SÜRDÜRÜLEBİLIRLIKK & 0.710 & 0.709 \\
\hline Çevresel Sürdürülebilirlik & 0.915 & 0.915 \\
\hline Ürün ve Hizmet & 0.836 & 0.836 \\
\hline İşyeri & 0.788 & 0.787 \\
\hline
\end{tabular}

Birinci Adım; Modelin değişkenleri tarafından açıklanan varyansı tespit etmek için $\mathrm{R}^{2}$ değerlerine bakılmıştır (Tablo 7). $\mathrm{R}^{2}$ değeri 0.190-0.332 zayıf; 0.333-0.669 orta; 0.670 ve üzeri yüksek düzey şeklinde tanımlanmıştır (Henseler ve Ringle ve 
Sinkovics, 2009). Analizde, bağımsızlık alt boyutuna ait $R^{2}$ değeri 0.020 olup zayıf anlamlı, diğer $R^{2}$ değerleri 0,67 referans değerinden yüksek olduğundan yüksek düzeyde anlamlı olduğu gözükmektedir.

Íkinci Adım; araştırma modeli yol analizi ile faktörler arası ilişkiler analiz edilmiştir (Tablo 8). PLS ile araştırma modeli yol analizi, yeniden örnekleme (bootstrraping) yöntemi ile 5.000 örneklemle yapılmıştır (Hair, Sarstedt, Ringle ve Mena, 2012). Analiz sonunda elde edilen $\beta$ ( $\mathrm{O}^{\prime \prime}$; original sample) değerlerinin $\mathrm{t}$ ve p değerlerine bakılmaktadır. \%5 anlamlılık düzeyi için $p$ değerinin $<0.05$ ve $t$ değerinin $>1.96$ olması gerekir.

Tablo 8. Araştırma Modeli Yol Analizi ile Faktörler Arası İlişkiler Analizi

\begin{tabular}{|l|r|r|r|r|r|}
\hline \multicolumn{1}{|c|}{ Değişkenler } & $\begin{array}{c}\text { Original } \\
\text { Sample (O) }\end{array}$ & $\begin{array}{c}\text { Sample } \\
\text { Mean (M) }\end{array}$ & $\begin{array}{c}\text { Standard } \\
\text { Deviation } \\
\text { (STDEV) }\end{array}$ & $\begin{array}{c}\text { T Statistics } \\
\text { (IO/STDEV } \\
\text { I) }\end{array}$ & P Values \\
\hline ETİK İKLIM -> KURUMSAL İTIBAR & 0.775 & 0.774 & 0.030 & 25.519 & 0.000 \\
\hline ETİK İKLIM -> SÜRDÜRÜLEBİL̇RLIK & 0.740 & 0.739 & 0.031 & 23.536 & 0.000 \\
\hline K. İTİBAR -> SÜRDÜRÜLEBİL̇RLIK & 0.638 & 0.637 & 0.047 & 13.491 & 0.000 \\
\hline $\begin{array}{l}\text { ETİK İKLİM -> KURUMSAL İTİBAR -> } \\
\text { SÜRDÜRÜLEBİLİRLIK }\end{array}$ & 0.494 & 0.493 & 0.043 & 11.478 & 0.000 \\
\hline
\end{tabular}

Hipotez Değerlendirme; \%5 anlamlılık düzeyi için p değerinin $<0.05$ ve t değerinin $>1.96$ 'ten büyük olması gerekmektedir. Tablo 8' de verilen analiz sonucuna göre, değişkenler arası ilişkilerin anlamlı olduğu, ayrıca aracılı model olduğu için Baron ve Kenny'nin dört aşamalı aracı kontrolüne de bakılarak gerekli şartları sağladığı görülmektedir. Böylece, bu analizler sonrası H1, H2, H3, H4 hipotezerinin desteklendiği tespit edilmiştir.

\section{Q2 Endojen Değişkenlerin Tahmin Gücü Analizi}

Araştırmada $Q^{2}$ PLS Blindfolding analizi yapılmıştır (Hair, Hult, Ringle ve Sarstedt, 2016). Q² Endojen değişkenlerin tahmin gücü analizinde $\mathrm{Q}^{2}$ değeri > 0; 0.02-0.15 ise küçük; 0.15-0.35 orta, 0.35 üstü ise yüksek tahmin gücünü ifade etmektedir (Tablo 9). Yapısal doğrulanmış çapraz geçerlilik kümeleri analizi (CCC- Construct Crossvalidated Communality) araştırma değişkenlerinin tahmin gücü ve ölçüm modeli kalitesinin, yapısal çapraz geçerlilik fazlalığ (CCR- Construct Crossvalidated Redundancy) araştırma modelinin kalitesinin göstergesidir (Duarte ve Raposo, 2010).

Tablo 9. Q² Değişkenlerin Tahmin Gücü Analizi

\begin{tabular}{|c|c|c|}
\hline Değişkenler & CCR & $\mathrm{CCC}$ \\
\hline Bagımsızlık & 0.012 & 0.256 \\
\hline Başkalarının İyiliğini İsteme & 0.451 & 0.418 \\
\hline Duygusal Çekicilik & 0.591 & 0.480 \\
\hline ETIK İKLIMM & & 0.425 \\
\hline Ekonomik Sürdürülebilirlik & 0.513 & 0.444 \\
\hline Finansal & 0.459 & 0.389 \\
\hline KURUMSAL İTIBAR & 0.321 & 0.455 \\
\hline Kanun ve Kodlar & 0.582 & 0.517 \\
\hline Kurallar & 0.548 & 0.496 \\
\hline Liderlik & 0.588 & 0.488 \\
\hline Sosyal Sorumluluk & 0.473 & 0.450 \\
\hline Sosyal Sürdürülebilirlik & 0.482 & 0.391 \\
\hline SÜRDÜRÜLEBİLIRLIKK & 0.348 & 0.418 \\
\hline Çevresel Sürdürülebilirlik & 0.473 & 0.405 \\
\hline Ürün ve Hizmet & 0.591 & 0.541 \\
\hline İşyeri & 0.559 & 0.481 \\
\hline
\end{tabular}

Toplanan verilerle oluşturulan modelin değişken tahmin gücünü göstermektedir. Buna göre bağımsılık tahmin gücü düşük, duygusal çekicilik, kanunlar, kodlar, kurallar, ürün-hizmet, işyeri, sosyal sorumluluğun tahmin gücü yüksek gözükmektedir.

\section{Model Uygunluğu ve Model Tahmin Gücü Analizi}

$\mathrm{Bu}$ kısımda araştırma modelinin uygunluğu sistem tarafından bir hesaplama ile analiz edilmektedir. Bu analizde kullanılan "Standartlaştırılmış Hata Kareler Ortalamasının Karekökü" (SRMR), model uyumsuzluk göstergelerinden biridir (Henseler vd., 2014). Bu analiz bir çeşit sağlamadır. Referans değerleri şöyledir; SRMR 
$\leq$ 0.08; RMStheta $\leq 0.12$. SRMR için norm değer $\leq 0.08$ olduğundan ve bu araştırma modeli değeri 0.078 bulunduğundan modelin uygun olduğu görülmüştür.

Araştırmanın ikinci aşamasındaki "Hata Kareler Ortalamasının Karekökü (RMS theta)" dış model değişkenlerinin korelasyonunun analizidir (Henseler vd., 2014). Araştırma modelinin tahmin gücü analiz değerinin $\leq 0.12$ olması gerekir (Hair, Black, Babin ve Anderson, 2010). PLS RMS theta değeri 0,123 bulunmuştur.

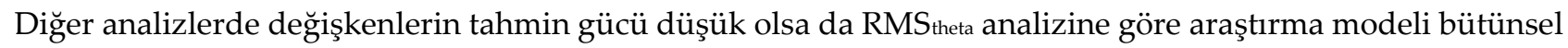
olarak değerlendirildiği zaman uygun bir modeldir.

Model uygunluk analizinin üçüncü ve son kısmında ise modelin içindeki uyumu gösteren "Model Uyum Derecesi Analizi (GoF)"dir. GoF için PLS'in bir analizi yoktur fakat şu formül önerilmektedir (Tenenhaus, Vinzi, Chatelin ve Lauro, 2005): $\mathrm{GoF}=\sqrt{ }(\mathrm{AVE} X \mathrm{R} 2)$ ve norm değerleri Tablo 10'da yer almaktadır.

Tablo 10. Model Uyum Derecesi (GoF) Analizi İçin Norm Değerler (Wetzels vd., 2009).

GoF değeri $<0,1$ model uygun değildir.

GoF değeri 0,1 ile 0,25 arasında ise model uygunluk açısından zayıf

GoF değeri 0,26 ile 0,36 arası ise model uygunluk açısından orta

GoF değeri >0,37 ise model uygunluk açısından yüksektir.

Araştırma modelinin GoF analiz değeri 0,709 olarak hesaplanmıştır. Buna göre model hem uygun hem güçlü bir modeldir diyebiliriz.

6. Araştırma Modeli Önemlerine Göre Performans Haritası Analizi (IPMA)

IPMA, araştırmada performansı yüksek olan ve bağımlı değişkenin üzerinde etkisi önemli olan değişkenleri tespit ve analiz etmektedir (Palos-Sanchez, Martin-Velicia ve Saura, 2018). Değişkenlerin analiz değerleri 0100 arasında bulunmaktadır. Önem açısından ise -1 ile +1 arasında regresyon değerleri verilmektedir. Önem ve performans haritası analizi, araştırmada hangi faktörlerin daha etkili olduğunu göstermektedir. Aşağıda kurumsal sürdürülebilirliğin önem performans haritası yer almaktadır (Şekil 3).

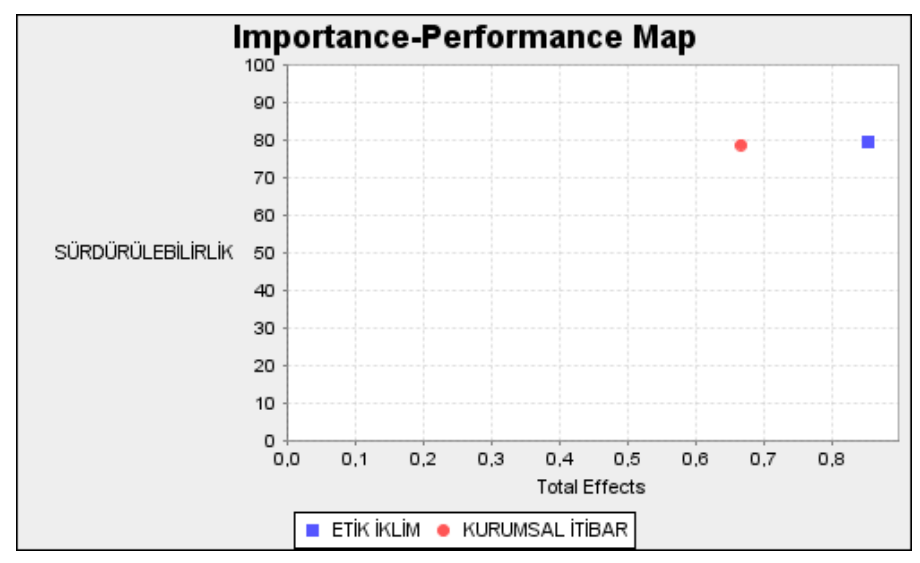

Şekil 3. Önemlerine Göre Performans Haritası - Sürdürülebilirlik

Şekil 3'e göre sürdürülebilirlik üzerinde önemi ve etkisi en yüksek olan değişken etik iklimdir, bunu kurumsal itibar yakından takip etmektedir.

\section{SONUÇ VE TARTIŞMA}

Kurumların varoluş ve sürdürülebilirliğinde normlar, inançlar, değerler, etik kodlar, kurumsal kural ve yasalara uyum büyük önem taşır. Kurumda etik iklime yönelik olan ve kurumu sürdürülebilir kılan uygulamaların kurum itibarını artırması, bu itibarın da sürdürülebilirliğe tekrar girdi olarak katılması söz konusudur. Bu unsurlar kurumun aksamadan çalışması için stratejik bir öneme sahiptir.

Yöneticiler açısından etik iklimin kurumsal sürdürülebilirlik uygulamalarına etkisinde kurumsal itibarın rolünün olup olmadığının sorgulandığı bu çalışma için kapsamlı bir literatür taraması ve araştırma yapılmıştır. Araştırma bulguları araştırma sorusuna olumlu cevap ortaya çıkartmıştır. Bu çalışma özgün ve üç 


\section{G. Ayral - N. Saracel 13/3 (2021) 2376-2395}

değişkenin aynı anda yer aldığı kapsamlı bir çalışma olması sebebiyle, karşılaştırma yapılacak birebir aynı içerikte çalışma bulunamamasına rağmen, fikir vermesi açısından benzer nitelikte tekli, ikili, üçlü kombinasyonlu araştırmalarla ile kıyaslama yapılmıştır.

Etik İklim ve Kurumsal Sürdürülebilirlik Kombinasyonunda; Lee ve Ha-Brookshire'ın (2017) "Moda Perakende Çalışanlarının İşten Ayrılma Niyetinde, Etik iklim, İş tutumu, ve Algılanan örgütsel sürdürülebilirlik performansı: Kesitsel bir çalışma" isimli makalesinde, $\mathrm{H}_{1}$ hipotezi olan, "Etik iklim, ABD moda perakende işletmelerinin sürdürülebilirlik üç alt boyutunu olumlu etkilemektedir (finansal, Sosyal, çevresel performans) hipotezinin desteklendiği sonucu çıkmıştır. Zaim ve İştar'ın (2011) “Aile İşletmelerinin Sürdürülebilirliğinde İş Etiğinin Etkisi: Trabzon İlinde Bir Uygulama" isimli çalışmasında $\mathrm{H}_{1}$ "İşs etiği alt boyutlarının ekonomik sürdürülebilirliğe anlamlı etkisi vardır" ve $\mathrm{H}_{2}$ "İş etiği alt boyutlarının ilişkisel sürdürülebilirliğe anlamlı etkisi vardır" hipotezlerinin desteklendiği sonucu çıkmıştır. Bu sonuçların, çalışmanın "H1: Yöneticiler açısından etik iklimin kurumsal sürdürülebilirlik uygulamalarına etkisi vardır" hipotezi ile uyumlu olduğu görülmektedir.

Etik İklim ve Kurumsal İtibar Kombinasyonunda; Öncel ve Yıldız (2012) “Kurumsal İtibarın Örgütsel Kimlik Üzerindeki Etkisinde Etik İklimin Moderatör Rolü"regresyon analizi ile incelenmiş, sonuçta hipotezin desteklendiği ortaya çıkmıştır. Ordu'nun (2012) “İş ahlakının Kurumsal İtibar Üzerindeki Etkisi”ne yönelik araştırmasında, iş ahlakı boyutlarından işletme uygulamaları ile kurumsal itibar arasında ilişki/etki vardır hipotezi, korelasyon ve çoklu regresyon yöntemiyle analiz edilmiş ve pozitif yönde etkisi olduğu sonucu ortaya çıkmıştır. Günel'in (2016), “İşletmelerde Etik Liderliğin Etik İklim Üzerindeki Etkisi ve Bir Uygulama” isimli çalışmasında, "etik liderlik etik iklimi pozitif yönde etkilemektedir" hipotezi regresyon modeli ile test edilmiş hipotezin desteklendiği görülmüştür. Çiçek'in (2017), “Kurumsal İtibarın Kazanılmasında Kurumsal Sosyal Sorumluluk Bilincinin ve Etik Yaklaşımın Rolü" isimli çalışmasında, etik davranış ve kurumsal sosyal sorumluluk uygulamaları ile kurumsal itibar kazanılıp, uzun dönemli büyüme sağlanabileceği sonucuna ulaşılmıştır. Leiva'nın (2014), "Kurumsal İtibar ve Kurumsal Etik; İyi Görünmek ya da İyi Yapmak" isimli çalışmasında, kurumların itibarlarını artırmak için değil kendi başına bir amaç olarak sosyal sorumluluk çalışmaları yapmaları gerektiği sonucuyla birlikte sosyal ve etik kurumsal uygulamaların itibar kazancı sağlayacağı sonucuna ulaşılmıştır. Walker ve Dyck'in (2014), "Kurumsal İtibarda Kurumsal Sosyal Sorumluluk ve Etikliğin Birincil Önemi: Ampirik Bir Çalışma" isimli çalışmasında, bir kurumun itibarını ölçmede etik kriterin kârlılık kriterinden daha çok etkili olduğunu vurgulamaktadır. Tüm yukarıdaki çalışmalar, bu çalışmanın kabul edilen " $\mathrm{H}_{2}$ : Yöneticiler açısından etik iklimin kurumsal itibara etkisi vardır" hipotezi ile uyum göstermektedir.

Kurumsal İtibar ve Sürdürülebilirlik Kombinasyonu; Zhu ve arkadaşlarının (2014) "Kurum Sosyal Sorumluluğu, Kurum İtibarı ve Firma Performansında Etik Liderliğin Rolü" isimli çalışmalarında, kurum itibarının firma performansını pozitif etkilediği hipotezinin, sonuçta desteklendiği görülmüştür. Performans burada ekonomik sürdürülebilirlik ile ilişkilendirilebilir. Diri'nin (2013), “Kurumsal İtibarın Performansa Etkisi: Konya'daki Özel Öğretim Kurumlarında Bir Araştırma" isimli çalışmasında, "Kurumsal itibar ile performans arasında bir ilişki söz konusudur" şeklindeki $\mathrm{H}_{1}$ hipotezinin desteklendiği görülmüştür. Yukarıda sayılan çalışmalar ile bu çalışmanın analizler sonucunda kabul edilen $\mathrm{H}_{3}$ : Yöneticiler açısından kurumsal itibarın kurumsal sürdürülebilirliğe etkisi vardır hipotezi ile uymuludur.

Etik İklim, Kurumsal itibar ve Kurumsal Sürdürülebilirlik Kombinasyonu; Üçlü kombinasyon alanında birebir aynı olmasa da yapılan benzer içerikli çalışma, Saylı ve arkadaşlarının (2009), "Etik, Kurumsal İtibar ve Kurumsal Performansa İlişkisini Belirlemeye Yönelik İlk 500 İşletme İçinde Yapılmış Bir araştırma" isimli çalışmasıdır. Bu çalışmanın "Etik, kurumsal itibar ve kurumsal performans arasında bir iliski var mı?" ana sorusuna, "etik ilkelerin varlığıyla kurumsal itibar arasında bire bir kuvvetli bir pozitif ilişki vardır" sonucu çıkmıştır. Ayrıca finansal göstergelere dayalı işletme performansıyla kurumsal itibar arasında anlamlı bir ilişki çıkmazken, kalite, müsteri memnuniyeti ile kurumsal itibar arasında \%95 güven aralığında anlamlı ilişkiler görülmekte olduğu raporlanmıştır. Literatürde benzer içerikte başka bir çalışmaya ratlanmamıştır. Bu çalışmada etik ilke ile kurumsal itibar arasında desteklenen $\mathrm{H}_{2}$ hipotezi ile uyumu vardır. Yine bu çalışmada ana hipotezlerle test edilmese de finansal yapının kurumsal itibara etkisinin olduğu detaylı alt boyut analizlerinde çıkmıştır. Bu sonuç Saylı ve arakadaşlarının (2009) çalışmasında uyumlu olmayan kısımdır. 
Kurumsal itibarın, etik iklimin sürüdürülebilirlik uygulamalarına etkisine aracılık edip etmediği ise literatürde yer almadığından, yeni bir katkı sunmak üzere özgün dördüncü hipotez olarak araştırmaya eklenmiş, $\mathrm{H}_{4}$ hipotez analizler sonucunda kabul edilmiştir.

Yapılan tüm tanımlayıcı istatistik çalışmaları (anket, demografik vb.), araştırma modeli analizleri (Yapısal Eşitlik Modeline bağlı tüm geçerlilik, güvenilirlik ve araştırma modeli yol analizleri), literatür ve başka araştırmalarla karşılaştırma analizleri ile bunların yorumlanmaları sonucunda; Etik iklimin Kurumsal sürdürülebilirlik ve itibar üzerinde etkisi olduğu, kurumsal itibarın da sürdürülebilirlik uygulamalarına etkisi olduğu ortaya çıkmıştır. "Yöneticiler açısından etik iklimin kurumsal sürdürülebilirlik uygulamalarına etkisinde, kurum itibarının aracı rolü var mıdır?" temel sorusu olumlu cevaplanmıştır.

Bu sonuçlardan hareketle, kurum yöneticilerine ve araştırmacılara çeşitli öneriler sunulmaktadır.

\section{Kurum yöneticilerine öneriler;}

Kurumlara, uygulamalarında özellikle ürün-hizmet, kurumun çekim gücü, kanun ve etik kodlar konusuna önem vermeleri önerilmektedir.

Kurumsal etik iklim, itibar ve sürdürülebilirlik sağlanmasında çalışanların kurum algısı çok önemlidir. Kurumlar, dış paydaşa yönelik ne kadar emek ve maliyete katlansa da çalışanını memnun etmedikçe çabaları eksik kalacaktır.

Edinilmesi zaman ve emek alan, kaybı kolay olan itibarın ölçümlerinin yapılması, korunması ve geliştirilmesi sürdürülebilirlik için gereklidir.

Kurumlar, içinde bulundukları çevreyi, paydaşları korumak, sorunlarına çözüm üretmek zorundadırlar. Aksi taktirde çevre ve paydaşlar tarafından dışlanacak, yerlerini korumakta, tekrar sisteme dahil olmakta zorlanacak, daha yüksek maliyete katlanmak durumunda kalacaklardır. Stratejilerde çevre ve paydaşlar göz önünde bulundurulmalıdır.

Kurumsal Sürdürülebilirlik uygulamalarında referans kılavuz, standart ve ilkeler takip edilmelidir. Sadece bu takip ve uyum çalışması bile kurumların kalitesini, bakış açısını olumlu yönde geliştirecektir.

Etik iklim, kurumsal itibar ve sürdürülebilirlik konularıyla ilgili eğitimler ve uygulamalar planlanmalı, etik kod sistemi geliştirilmelidir.

Etik, sürdürülebilirlik, kurumsal itibar; akademik, toplumsal ve kurumsal eğitim süreçlerine katılmall, okullarda ve özellikle üniversitelere ders olarak okutulmalıdır.

\section{Araştırmacılara öneriler;}

Araştırma, zaman ve maliyet kısıtı sebebiyle yalnızca yöneticilerle ve belli bir zaman aralığında yapılmıştır. Gelecekte, diğer paydaş bakış açılarının araştırıldığı ya da farklı dönemlerde yönetici araştırma verilerinin analiz edilerek önceki araştırmalarla karşılaştırılacağı araştırmalar yapılabilir.

Kurumlarda sürdürülebilirlik konusunda ölçüm yapılıp, algı ile gerçekleşen karşılaştırması analiz edilebilir.

Avrupa Birliği tarafından 2019 yılında oluşturulan Yeşil Anlaşma (Green Deal), karşılıklı ekonomik, sosyal ve siyasal ilişkide olduğu Türkiye ile kurumlarını yakından ilgilendirmektedir. Bu anlaşmaya göre uygulamada kurumlardan neler beklenildiği, iş yapış şekillerini nasıl etkileyeceği konusunda araştırmalar yapılabilir.

Sonuç olarak, kurumlar etik iklim temelinde organizasyonlarının ve paydaşlarının refahını artırmaya çalışarak; işsizlik, yolsuzluk, açlık, yoksulluk ve hastalıklarla mücadele ederek; eşit sağlık-eğitim-iş-gelir imkanları konusunda uygulamalar yaparak; doğal kaynakları ve çevreyi koruyarak, tüm canlıların bugün ve yarın için yaşam haklarına saygı göstererek kendilerini gerçekleştirebilecekler, kurumsal ve toplumsal sürdürülebilirliğe katkı sağlayacaklardır. 


\section{KAYNAKÇA}

Akdoğan, A.A. ve Cingöz, A. (2009). Kurumsal itibar ve kriz yönetimi: kurumsal itibarı.

Aksoy, Ç. (2013). Sürdürülebilirlik performansının değerlendirilmesine yönelik ölçek önerisi ve Türkiye'deki işletmelerde uygulaması. (Doktora tezi), İstanbul: Marmara Üniversitesi Sosyal Bilimler Enstitüsü, İstanbul.

Asif, M., Searcy, C., Zutshi, A. ve Ahmad, N. (2011). An integrated management systems approach to corporate sustainability. European Business Review, 23(4), 353-367.

Ayral, G. (2021). Yöneticiler Açısından Etik İlimin Kurumsal Sürdürülebilirlik Uygulamalarına Etkisinde Kurum İtibarının Rolü (Doktora Tezi), Doğuş Üniversitesi Lisansüstü Eğitim Enstitüsü, İstanbul

Bal, C. G., Ada, S. ve Çelik, A. (2012). Bilişim sistemleri başarı modeli ve aile hekimliği bilişim sistemleri. Yönetim ve Ekonomi Dergisi, 9(1), 35-46.

Baron ve Kenny, (1986), 1176. Aktaran; Yücel, İ. ve Koçak D. (2017). İş tatmini ve işten ayrılma niyeti arasındaki ilişkide tükenmişliğin aracılık etkisi: Sağlık sektöründe bir çalışma, Üçüncü Sektör Sosyal Ekonomi, 52 (2) :31-55

Barnett, T. ve Schubert, E. (2002). Perceptions of the ethical work climate and covenantal relationships. Journal of Business Ethics, 36,279-290.

Bibri, M. (2008). Corporate Sustainability / CSR Communications ve Value Creation: A Marketing Approach, School of Management Blekinge Institute of Technology, Master of Business Administration (MBA), Sweden, Spring, Erişim adresi: https://www.diva-portal.org/smash/get/diva2:831498/FULLTEXT01.pdf, Erişim tarihi: 29.10.20.

Birleşmiş Milletler (2016). About the Sustainable Development Goals. Erişim adresi: https://www.un.org/sustainabledevelopment/sustainable-developmentgoals/. . Erişim Tarihi: 01.11.2020

Bozkurt, M. (2011) Kurumsal İtibar Yönetiminin Müşteri Değerlendirme Sürecine Yansıması ve Etkileri: Konaklama İşletmelerine Yönelik Bir Uygulama. Balıkesir Üniversitesi Sosyal Bilimler Enstitüsü, Yayınlanmamış Doktora Tezi, Balıkesir.

Brundtland, G. (1987). Report of the world commission on environment and development: Our common future. Birleşmiş Milletler Genel Asamblesi Belgesi, No. A/42/427)

Colantonio, A. (2009). Originally published in Horner, M., Price, A., Bebbington, J. and Emmanuel, R., (eds.) SUE-Mot Conference 2009: Second International Conference on Whole Life Urban Sustainability and its Assessment: conference proceedings, (865-885) Loughborough: Loughborough University. Erişim adresi: http://eprints.lse.ac.uk/35867/1/Colantonio Social sustainability review 2009.pdf

Cullen, J.B, Victor, B. ve Bronson, J.W. (1993). The ethical climate questionnaire: an assessment of its developement and validity. Psychological Reports, 73, 667-674

Cullen, J. B., Parboteeah, K. P. ve Victor, B. (2003). The effects of ethical climates on organizational commitment: A two-study analysis, Journal of Business Ethics, 46,127-141.

Çiçek, E. ( 2017), Kurumsal İtibarın Kazanılmasında Kurumsal Sosyal Sorumluluk Bilincinin ve Etik Yaklaşımın Rolü, Selçuk Üniversitesi Sosyal ve Teknik Araştırmalar Dergisi Sayı: 13, 2017, ss. 194-218

Çiftçioğlu, B.A. (2009). Kurumsal itibar yönetimi. Ankara: Dora Yayınları.

Çokluk, Ö., Şekercioğlu, G. ve Büyüköztürk, Ş. (2010). Sosyal Bilimler İçin çok Değişkenli İstatistik: SPSS ve Lisrel uygulamaları. Ankara: Pegem Akademi Yayıncılık.

Demir, Y. (2006). İş etiği kavramı ve işletmeler açısından önemi. Üçüncü Sektör Kooperatifçilik, 41(1),87-98.

Dinçer, Ö. (2003). Stratejik yönetim ve işletme politikası.. İstanbul: Beta Basım Yayım.

Dörtok, A. (2004). Kurumsal itibarınızdan kaç sıfır atabilirsiniz?, İstanbul: Rota Yayınları. 


\section{G. Ayral - N. Saracel 13/3 (2021) 2376-2395}

Duarte, A.P., ve Raposo, M.L. (2010). A PLS model to study brand references: An application to the mobile phone market. V. E. Vinzi, W. W. Chin, J. Henseler, ve H. Wang içinde, Handbook of partial least squares: Concepts, methods and applications. Berlin: Springer.

Dyllick, T. ve Hockerts, K. (2002). Beyond the business case for corporate sustainability, Business Strategy and the Environment, 11(2),130-141.

Elçi, M., Alpkan, L. (2006). Etik iklimin örgütsel vatandaşlik davranişlarina etkileri, H.Ü. İktisadi ve İdari Bilimler Fakültesi Dergisi, 24(1),141-170).

Feng Y. Z. , Elmasry G, Sun D. W., Scannell A. G., Walsh D, Morcy N, (2013). Near-infrared hyperspectral imaging and partial least squares regression for rapid and reagentless determination of Enterobacteriaceae on chicken fillets. Food Chemistry 138.2 (2013): 1829-1836.

Fritzshe, D.J. (2000). Ethical climate and the ethical dimensions of decision making. Journal of Business Ethics.

Falk, R.F. and Miller, N.B. (1992). A Primer for Soft Modeling. University of Akron Press, Akron

Fombrun, C., J., G., N., A., ve Sever, J.M. (1999). The reputation quatient: A multi-stakeholder measure of reputation, The Journal of Brand Management, 7(4),241-255.

Fombrun, C.J., Shanley, M. (1990). “What's in a name? Reputation building and corporate strategy. Academy of Management Journal, 33(2), 233-258.)

Fortune 500. Erişim adresi: https://www.fortuneturkey.com/fortune500, Erişim tarihi: 05.11.2019

Fornel, C. ve Larcker, D.F. (1981). Evaluating structual equation models with unobservable variables and mesaurement error. Journal of Marketing Research, 18(1),39-50.

Freeman, R.E. (1984), Strategic management: A stakeholder approach, pitman, Boston: MA.

Gellerman, S.W. (1973). The uses of pyschology in management. New York: Coller. Aktaran;

Gotsi, M. ve Wilson, A.M. (2001), Corporate reputation: Seeking a definition, Corporate Communications: An International Journal, 6(1),24-30.)

Gözükara, E. (2019). Isşletme ve Sürdürülebilirlik, 21. Yüzyıl'da Sürdürülebilirlik: Sosyal Bilimlere Dayalı Perspektifler, Editör: Evren Ayrancı Birinci Baskı: Eylül 2019, İstanbul.

Günel, D. (2016). İşletmelerde Etik Liderliğin Etik İklim Üzerindeki Etkisi ve Bir Uygulama, Yüksek Lisans Tezi, İstanbul Ticaret Üniversitesi, Sosyal Bilimler Enstitüsü, İşletme Anabilim Dalı, İstanbul

Güngör Tanç, Ş. (2019). Kurumsal Sürdürlebilirlik Faaliyetlerinin Firma Değeri Üzerine Etkisi: Bist 100 Örneği, İşletme Araştırmaları Dergisi, 11 (3), 2076-2083.

Hair, J.F., Black, W.C., Babin, B. ve Anderson, R.E. (2010). Multivariate data analysis. New Jersey: Prentice Hall..

Hair, J.F., Sarstedt, M., Ringle, C.M. ve Mena, J. (2012). An assessment of the use of partial least squares structural equation modeling in marketing research. Journal of the Academy of Marketing Science, 40(3), 414-433.

Hair, J.F., Hult, G.T., Ringle, C.M. ve Sarstedt, M. (2016). A Primer on Partial Least Squares Structural Equation Modeling (PLS-SEM). Thousand Oaks: Sage.

Hahn, T. ve Scheermesser, M. (2006). Approaches to corporate sustainability among german companies, Corporate Social Responsibility and Environmental Management, 13(3), 150-165.

Henseler, J. Dijkstra, T.K., Sarstedt, M., Ringle, C.M., Diamantopoulos, A. ve Straub, D.W. (2014). Common beliefs and reality about partial least squares. Organizational Research Methods, 17(2),182-209.

Henseler, J., Ringle, C.M. ve Sinkovics, R.R. (2009). The use of partial least squares path modeling in international marketing. Advances in International Marketing, 20, 277-319. 
https://www.ayk.gov.tr/wp-content/uploads/2015/01/SEZER-Özcan-KÜRESEL-KONFERANSLAR-VEÇEVRE-SORUNLARI-ÇEVRE-KALKINMA-VE-ETIK-AÇISINDAN-ELEŞTİREL-BİRDEĞERLENDİRME.pdf, Erişim Tarihi: 29.09.2020

https://www.un.org/sustainabledevelopment/,Erişim Tarihi: 13.08.2020).

Inglis, R.C., Clive, M. ve Sammut P. (2006). Corporate reputation andorganisational performance: an Australian study. Managerial Auditing Journal.

Kaplan, M. (2011). Otel işletmelerinde etiksel iklim algılamaları ile örgütsel bağlılık arasındaki ilişkinin analizi: Kapadokya örneği. Dumlupınar Üniversitesi Sosyal Bilimler Dergisi, 30,191-206.

Karasar, N. (2009). Bilimsel araştırma yöntemleri, Ankara: Nobel Yayınları

Karaköse, T. (2006). Örgütlerde itibar yönetimi. Akademik Bakış: Uluslararası Hakemli Sosyal Bilimler E-Dergisi, Sayı:11,

Karaköse, T. (2007). Kurumların DNA'sı itibar ve yönetimi, Ankara: Nobel Yayınları.

Karatepe, S. (2008). İtibar yönetimi: Halkla ilişkilerde güven yaratma, Elektronik Sosyal Bilimler Dergisi, $7(23), 82$.

Kuşat, N. (2012) Sürdürülebilir işletmeler için kurumsal sürdürülebilirlik ve içsel unsurları. Afyon Kocatepe Üniversitesi İ̈BF Dergisi, 14(2), 227-242.

Küçükoğlu, M.T. (2014). Sürdürülebilirlik ve yeşil yenilik perspektifinde Türk işletmelerin incelenmesi. Doktora Tezi, İstanbul Üniversitesi.

Leaniz, P.M.G. ve Bosque, I.R. (2013). Relational capital: The role of sustainability in developing corporate reputation, Poceedings of the International Conference on Intellectual Capital, 539-547.

Lee, S.H. ve Ha-Brookshire, J. (2017). Ethical climate and job attitude in fashion retail employees' turnover intention, and perceived organizational sustainability performance: A cross-sectional study. Sustainability, 9, 465

McGill University. (2018). What is sustainability? Erişim adresi: https://www.mcgill.ca/sustainability/files/sustainability/what-is-sustainability.pdf Erişim tarihi: 01.11.2020

Mimms, M. (2010). Storied Stables: Social Engagements for Social Sustainability, Interior Design in Partial Fulfilment of the Requirements for the Degree of Master of Art Corcoran College of Art and Design, Washington, Dc, Spring.

Musteen, M., Datta, D.K. ve Kemmerer, B. (2010). Corporate reputation: do board characteristics matter?, British Journal of Management, 21,498-510.

Neubaum, D., Mitchell, M., Schminke, M. (2004). Firm newness, entrepreneurial orientation, and ethical climate, Journal of Business Ethics 52 (4), 335-347

Okay, A. ve Okay, A. D. (2005). Halkla iliskiler kavram, strateji ve uygulamaları, Istanbul: Der Yayınları.

Öncel, A.Z., Yıldız, M.L. 2012, The Impact of Ethical Climate on Relationship between Corporate Reputation and Organizational Identification, 8. International Strategic Management Conference

Özdemirci, A., Saruhan, S.C. (2016). Bilim, felsefe ve metodoloji, (4. Baskı). İstanbul: Beta Yayıncılık.

Özgener, Ş. (2002). İmalat sanayi isletmelerindeki kamu ve özel sektör yöneticilerinin is ahlâkına iliskin tutumları. Amme İdaresi Dergisi, 35(1),177.

Özpınar, B. (2008). Kurumsal itibarın ölçümü: Türkiye'ye yönelik ölçek geliştirme çalışması (Doktora tezi). Anadolu Üniversitesi Sosyal Bilimler Enstitüsü, Eskişehir).

Özmehmet, E. (2008). Dünyada ve Türkiye'de sürdürülebilir kalkınma yaklaşımları. Journal of Yaşar University, 3(12),1853-1876. 
Palos-Sanchez, P., Martin-Velicia, F. ve Saura, J.R. (2018). Complexity in the acceptance of sustainable search engines on the Internet: An analysis of unobserved heterogeneity with PLS-FIMIX. Complexity, 1-19.

Pehlivan, İ. (2001). Yönetsel, mesleki ve örgütsel etik. Ankara: Pegem A. Yayınevi.

Preacher, K. J., Rucker, D. D., \& Hayes, A. F. (2007). Addressing moderated mediation hypotheses: Theory, methods, and prescriptions. Multivariate behavioral research, 42(1), 185-227.

Sümer, N. (2000), Yeni başlayanlar için halkla ilişkiler, Türk Psikoloji Yazıları, 49-74

Tenenhaus, M., Vinzi, V.E., Chatelin, Y.M. ve Lauro, C. (2005). PLS path modeling. Computational Statistics ve Data Analysis, 48(1), 159-205.

Tonus Z.H., Tez, Ö.H. (2013). Farklı paydaşların kurumsal itibarı değerlendirmelerindeki farklılı̆̆ın sosyal ve finansal performans algılarıyla ilişkisi. Dumlupınar Üniversitesi Sosyal Bilimler Dergisi, 35,1-12.

Tuna, Ö. (2014). Kurumsal sürdürülebilirlik yaklaşım ve uygulamaları: Kobi'lere yönelik bir araştırma. (Doktora tezi) Afyon Kocatepe Üniversitesi, Sosyal Bilimler Enstitüsü, Afyon.

Türk, S.M. ve Güven A. (2007). Yeni başlayanlar için halkla ilişkiler. Ankara: Gazi Kitabevi.

Urbach, N. ve Ahlemann, F. (2010). Structural equation modeling in information systems research using partial least squares. Journal of Information Technology Theory and Application, 11(2), 5-40.

Victor, B. ve Cullen, J.B. (1987). A theory and measure of ethical dimates in organizations. Research in Corporate Social Performance and Policy, 9, 51-71),

Victor B. ve Cullen J.B. (1988). The organizational bases of ethical work climate, Administrative Science Quarterly.

WACOSS Western Australian Council of Social Services. Aktaran; Tuna, 2014

Walker, K., Dyck, B. (2014). The Primary Importance of Corporate Social Responsibility and Ethicality in Corporate Reputation: An Empirical Study, Business and Society Review, Vol. 119:1, pp. 147-174.

Wetzels, M., Schröder, G.O. ve Van O.C. (2009). Using PLS path modeling for assessing hierarchical construct models: Guidelines and empirical illustration. MIS Quarterly, 177-195.

Willard, B.(2005) Next Sustainability Wave: Building Boardroom Buy-In, New Society Publishers, http://site.ebrary.com/id/10085541?ppg=50, Erişim Tarihi: 17.10.2019

Zaim, H , İştar, E . (2011). Aile İşletmelerinin Sürdürülebilirliğinde İşs Etiğginin Etkisi Trabzon İlinde Bir Uygulama. Düzce Üniversitesi Sosyal Bilimler Enstitüsü Dergisi, 5 (1) , 1-26.

Yazıcıoğlu, Y. ve Erdoğan, S. (2004). SPSS Uygulamalı Bilimsel Araştırma Yöntemleri, Ankara: Detay Yayıncilik.

Young, W. ve Tilley, F. (2006). Can businesses move beyond efficiency? The shift toward effectiveness and equity in the corporate sustainability debate, Business Strategy and the Environment, 15(6),402-415.

2020 Global Trends In Reputation, Erişim adresi: reputationinstitute.com. Erişim tarihi: 05.03.2020

A European Green Deal I European Commission (europa.eu), Erişim tarihi: 22.02.2 